\title{
A new tribe, two new genera and three new species of Cypridopsinae (Crustacea, Ostracoda, Cyprididae) from Brazil
}

\author{
Nadiny Martins de ALMEIDA ${ }^{\circledR 1}$, Janet HIGUTI ${ }^{\circledR}$ 2, \\ Vitor Góis FERREIRA ${ }^{\circledR 3}{ }^{3}$ \& Koen MARTENS $(\mathbb{4}$ 4,* \\ ${ }^{1,2,3}$ State University of Maringá (UEM), Centre of Research in Limnology, Ichthyology and \\ Aquaculture (Nupélia), Graduate Programme in Ecology of Inland Water Ecosystems (PEA). \\ Av. Colombo, 5790, CEP 87020-900. Maringá, PR, Brazil. \\ ${ }^{4}$ Royal Belgian Institute of Natural Sciences, Freshwater Biology, Vautierstraat 29, \\ 1000 Brussels, Belgium and Ghent University, Biology, \\ K.L. Ledeganckstraat 35, 9000 Ghent, Belgium. \\ *Corresponding author: darwinula@gmail.com,kmartens@naturalsciences.be \\ ${ }^{1}$ Email: nadinymartinsdealmeida@gmail.com \\ 22Email: janethiguti@gmail.com \\ ${ }^{3}$ Email: vgferreira@outlook.com \\ ${ }^{1}$ urn:lsid:zoobank.org:author:0C9E2B69-3A99-4185-9E24-017286D9D353 \\ ${ }^{2}$ urn:lsid:zoobank.org:author:3A5CEE33-280B-4312-BF6B-50287397A6F8 \\ ${ }^{3}$ urn:1sid:zoobank.org:author:1D07BA7A-7475-49CC-AD80-54FB2BF7CD61 \\ ${ }^{4}$ urn:lsid:zoobank.org:author:9272757B-A9E5-4C94-B28D-F5EFF32AADC7
}

\begin{abstract}
We describe one new tribe, two new genera and three new species of the subfamily Cypridopsinae Kaufmann, 1900 from Brazilian floodplains. Brasilodopsis gen. nov. belongs in the nominal tribe Cypridopsini, and both new species in this new genus were found in both sexual and asexual populations. Brasilodopsis baiabonita gen. et sp. nov. has a wide distribution and was found in three of the four major Brazilian floodplains. Brasilodopsis amazonica gen. et sp. nov. was recorded only from the Amazon floodplain. Brasilodopsis baiabonita gen. et sp. nov. has a subtriangular shape in lateral view, whereas Brasilodopsis amazonica gen. et sp. nov. is more elongated and has more rounded dorsal margins in both valves, as well as more pronounced external valve ornamentation, consisting of rimmed pores in shallow pits. Paranadopsis reducta gen. et sp. nov. was found in asexual populations in the Upper Paraná River floodplain only and differs from other Cypridopsinae in the more elongated carapace, an A1 with strongly reduced chaetotaxy (hence the specific name) and the total absence of caudal rami in females. Because of these strong reductions in valve and limb morphology, Paranadopsini trib. nov. is created within the Cypridopsinae for this intriguing new genus and species.
\end{abstract}

Keywords. Microcrustaceans, morphological characters, reduced chaetotaxy, Cyprididae, Neotropical.

Almeida N.M., Higuti J., Ferreira V.G. \& Martens K. 2021. A new tribe, two new genera and three new species of Cypridopsinae (Crustacea, Ostracoda, Cyprididae) from Brazil. European Journal of Taxonomy 762: 1-48. https://doi.org/10.5852/ejt.2021.762.1451 


\section{Introduction}

There are approximately 2330 species and 270 genera of living non-marine ostracods described. The most diverse family is the Cyprididae Baird, 1845, which has more than 20 subfamilies and comprises $43 \%$ of all species (Meisch et al. 2019). One of these subfamilies is the Cypridopsinae Kaufmann, 1900, which thus far comprises 20 genera. This subfamily is primarily common in the Afrotropical region, but it also occurs on all other continents, except for the Antarctic mainland (Meisch et al. 2019). The main characteristics that unite the species of this subfamily are the small carapace size (ca $0.3-0.9 \mathrm{~mm}$ length) and especially the reduced caudal ramus, usually with the shape of a flagellum in the females and fully absent in males (Meisch 2000).

Four tribes are thus far distinguished in this subfamily. The nominal tribe Cypridopsini is the most diverse with thus far 15 recognised genera. It now also comprises one of the two new genera described here, bringing it up to 16 nominal genera. The most speciose genus within this subfamily is Cypridopsis Brady, 1867, the type genus, with 66 nominal species, but most likely several of these would deserve a different generic assignment.

Here, we describe one new tribe, two new genera and three new species of Cypridopsinae from Brazilian floodplains. For one new genus and species, Paranadopsis reducta gen. et sp. nov., a new tribe Paranadopsini trib. nov. is erected, because of the strong reductions in size and chaetotaxy of segments on most limbs, mostly in the A1, which makes it unique in the subfamily. The present contribution brings the number of known cypridopsine tribes to five, and the number of genera to 21 .

\section{Material and methods}

\section{Study area}

The study area covers the four largest Brazilian floodplains: Amazon $\left(3^{\circ} 02^{\prime}-3^{\circ} 34^{\prime} \mathrm{S}, 60^{\circ} 50^{\prime}-60^{\circ} 10^{\prime} \mathrm{W}\right)$, Araguaia $\left(12^{\circ} 50^{\prime}-13^{\circ} 20^{\prime} \mathrm{S}, 50^{\circ} 40^{\prime}-50^{\circ} 30^{\prime} \mathrm{W}\right)$, Pantanal $\left(18^{\circ} 50^{\prime}-19^{\circ} 30^{\prime} \mathrm{S}, 57^{\circ} 40^{\prime}-57^{\circ} 00^{\prime} \mathrm{W}\right)$ and Upper Paraná $\left(22^{\circ} 40^{\prime}-24^{\circ} 00^{\prime} \mathrm{S}, 54^{\circ} 20^{\prime}-53^{\circ} 00^{\prime} \mathrm{W}\right)$ (Fig. 1).

\section{The Amazon River floodplain}

The Amazon River is the second longest river in the world and the largest in water volume, with an average flow rate of approximately 214 million litre per second. The Amazon River and its tributaries are accompanied along its middle and lower courses by large floodplains covering an area of about $300000 \mathrm{~km}^{2}$. Each year, the river rises more than nine meters, flooding the surrounding forests, known as the Várzea (Irion et al. 1997). The lakes sampled from the Amazon floodplain $\left(03^{\circ} 14^{\prime} \mathrm{S}, 59^{\circ} 58^{\prime} \mathrm{W}\right)$ are located near (ca $100 \mathrm{~km}$ or less of) the city of Manaus.

\section{The Araguaia River floodplain}

The Araguaia River has a length of $2110 \mathrm{~km}$ and can be divided into three units: high, medium and low Araguaia (Latrubesse \& Stevaux 2002). The upper Araguaia extends from the upper course (Serra dos Caiapós) to the city of Registro do Araguaia and has a length of $450 \mathrm{~km}$. The medium Araguaia, about $1160 \mathrm{~km}$ long, is located between the cities of Registro do Araguaia and Conceição do Araguaia. The lower Araguaia runs $500 \mathrm{~km}$ to its confluence with the Tocantins River (Aquino et al. 2008, 2009). The climate encompasses two well-defined seasons, rainy and dry, which control the variations of the discharge into the Araguaia River (Latrubesse \& Stevaux 2006). The sampling area is located in the middle region of Araguaia River (13⒉ $\left.21^{\prime} \mathrm{S}, 50^{\circ} 36^{\prime} \mathrm{W}\right)$.

\section{The Pantanal Sul Matogrossense and adjacent areas}

The Paraguay River is the most important tributary of the Paraná River and one of the main rivers of the La Plata Basin, the fifth largest basin in the world. The Pantanal is located in central South America in the Upper Paraguay River basin, which encompasses most of its area in Brazil (the State of Mato 

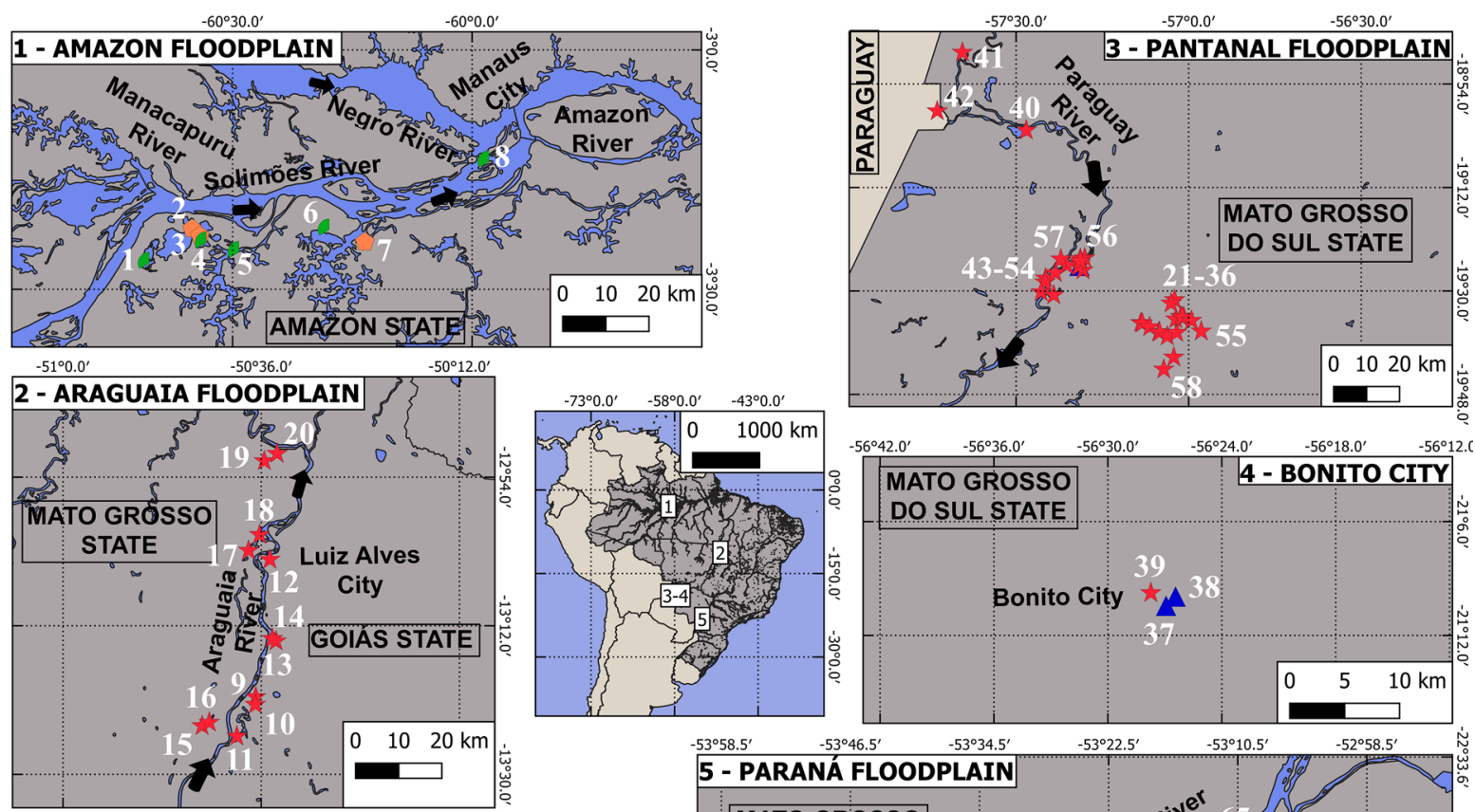

Species

- Brasilodopsis amazonica gen. nov. sp. nov. 우

Brasilodopsis amazonica gen. nov. sp. nov. 이

$\star$ Brasilodopsis baiabonita gen. nov. sp. nov.

A Brasilodopsis baiabonita gen. nov. sp. nov. $q ð$

- Paranadopsis reducta gen. nov. sp. nov. 우

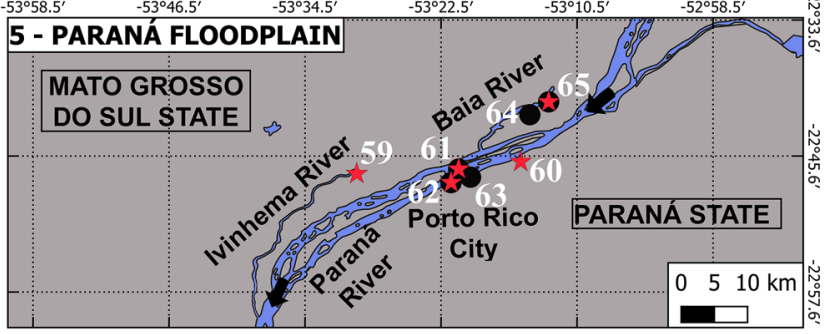

Fig. 1. Localities where Brasilodopsis amazonica gen. et sp. nov., Brasilodopsis baiabonita gen. et sp. nov. and Paranadopsis reducta gen. et sp. nov. were found. Locality names are in Table 4.

Grosso, known as the Pantanal of Mato Grosso, and the State of Mato Grosso do Sul, known as the Pantanal Sul Matogrossense) and extends into parts of Bolivia and Paraguay. The Upper Paraguay basin, in Brazilian territory, covers $393600 \mathrm{~km}^{2}$, of which $140000 \mathrm{~km}^{2}$ are floodplains and $253600 \mathrm{~km}^{2}$ are plateaus (Por 1995). In 2000, the Pantanal was officially named a Biosphere Reserve by UNESCO and awarded the World Heritage Certificate. The lakes sampled in the Pantanal $\left(19^{\circ} 02^{\prime} \mathrm{S}, 57^{\circ} 28^{\prime} \mathrm{W}\right)$ and adjacent areas (Bonito) are located in the State of Mato Grosso do Sul.

\section{The Upper Paraná River floodplain}

The Upper Paraná River floodplain $\left(13^{\circ} 13^{\prime} \mathrm{S}, 50^{\circ} 34^{\prime} \mathrm{W}\right)$ is located between the Porto Primavera and Itaipu Reservoir and is approximately $230 \mathrm{~km}$ long and $20 \mathrm{~km}$ wide. In this area, three units of conservation were created, owing to their high biodiversity and environmental heterogeneity: i) Área de Proteção Ambiental das Ilhas e Várzeas do Rio Paraná (100310 ha), ii) the Parque Nacional de Ilha Grande (78 800 ha), and iii) the Parque Estadual do Ivinheima (70000 ha) (Agostinho et al. 2004).

\section{Material}

The samples of ostracods used in this study were collected between 2004 and 2018.

Periphytic (associated with aquatic macrophytes) and benthic ostracods were collected from various types of environments (lentic and lotic) from four floodplains: Amazon, Araguaia, Pantanal Sul Matogrossense and Paraná (see above). The aquatic macrophytes: Azolla sp.; Eichhornia azurea (Sw.) Kunth, Eichhornia crassipes (Mart.) Solms, Lemna sp., Limnobium sp.; Ludwigia sp., Paspalum sp., Pistia sp.; Pistia stratiotes L., Ricciocarpos sp., Salvinia sp.; Salvinia auriculata Aubl., Salvinia minima 
Baker, Utricularia sp. were manually sampled, placed in plastic buckets (see Higuti et al. 2007; Campos et al. 2017) and washed to remove the ostracods associated with macrophytes. The samples were filtered in a net (160 $\mu \mathrm{m}$ mesh size) and were fixed in alcohol, buffered with sodium tetraborate. The ostracods were sorted under a stereoscopic microscope and stored in $70 \%$ alcohol.

\section{Morphological analyses}

The valves were opened with entomological needles, the soft parts were removed from the carapace and the appendages separated and mounted on a slide in a drop of glycerine, covered with cover slip and sealed with nail polish. The separated valves and the illustrated carapaces were stored dry in micropalaeontological slides.

The illustrations (drawings) of the appendages of the ostracods were made with the aid of a camera lucida (Olympus UDA) attached to transmission light microscope (Olympus CX-41). The valves were illustrated with scanning electron microscopy (SEM, Fei Qanta ESEM, RBINS, Brussels) in different views (valves: internal and details; carapaces: lateral, dorsal, ventral and details). Illustrations of limbs for each species were made from different specimens, because no single dissection had all limbs in the right position, owing to the very small size of the animals.

\section{Abbreviations used in text, tables and figures}

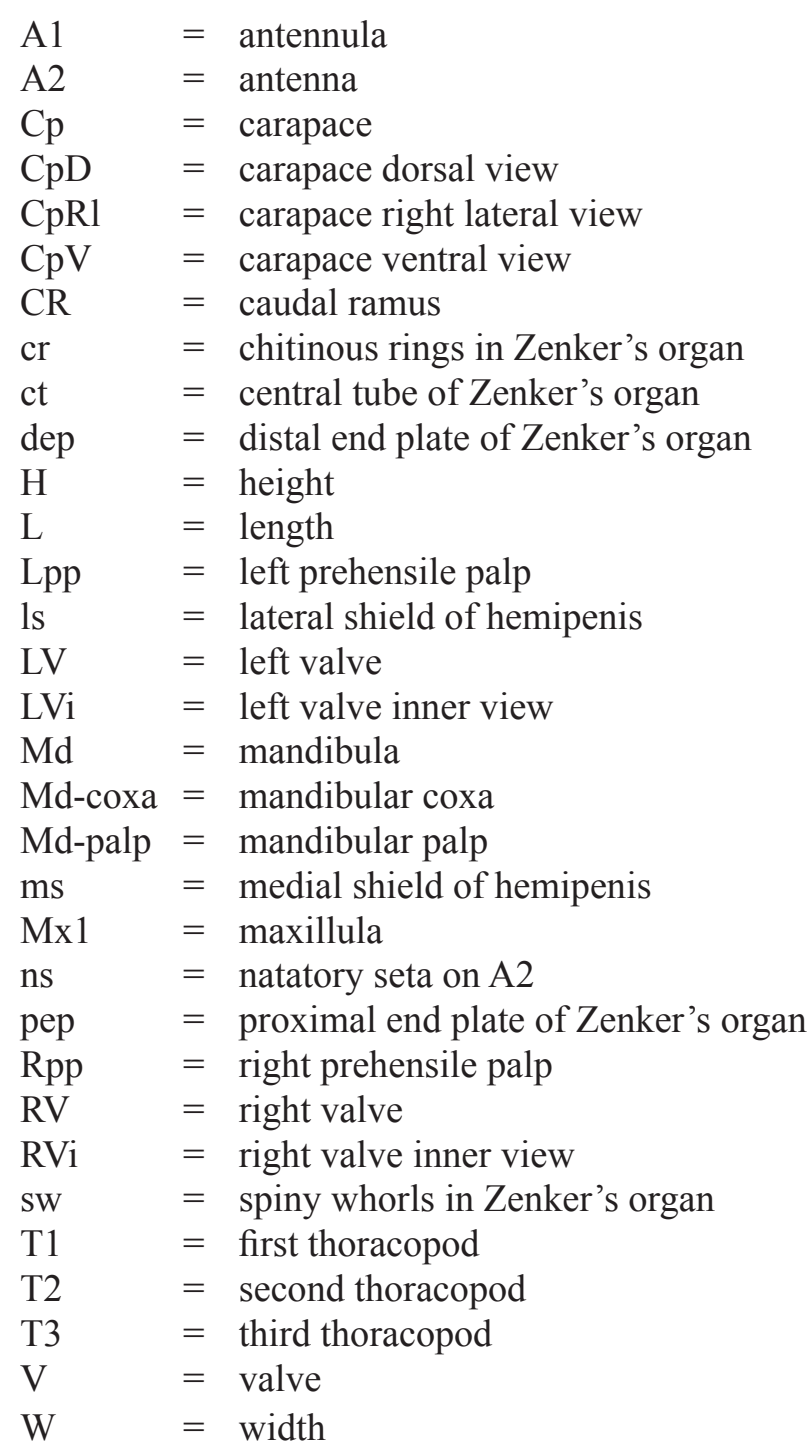


The type material and all illustrated specimens are stored in the Museum of Zoology of the University of São Paulo (MZUSP), São Paulo, Brazil. Some non-type and non-illustrated specimens will be stored at the State University of Maringá (UEM).

The nomenclature of the chaetotaxy of the limbs follows the model proposed by Broodbakker \& Danielopol (1982), revised for the A2 by Martens (1987) and for the T3 by Meisch (2000). Higher taxonomy of the Ostracoda follow the synopsis by Horne et al. (2002).

\section{Results}

Class Ostracoda Latreille, 1802

Subclass Podocopa G.O. Sars, 1866

Order Podocopida G.O. Sars, 1866

Suborder Cypridocopina Baird, 1845

Superfamily Cypridoidea Baird, 1845

Family Cyprididae Baird, 1845

Subfamily Cypridopsinae Kaufmann, 1900

Tribe Cypridopsini Kaufmann, 1900

Brasilodopsis gen. nov.

urn:1sid:zoobank.org:act:4AAADA13-1225-4927-A258-42AE8DF369BC

\section{Type species}

Brasilodopsis baiabonita gen. et sp. nov. (here described and designated).

\section{Other species}

Brasilodopsis amazonica gen. et sp. nov. (here described).

\section{Etymology}

The name of the new genus is a contraction of 'Brasilo', after Brazil, the country from which it is here described, and 'dopsis', referring to the stem of Cypridopsis.

\section{Diagnosis}

Cp sub-triangular in lateral view, with LV mildly overlapping RV along all sides. LV anteriorly, ventrally and posteriorly with a well-developed, largely inwardly displaced inner list, anteriorly with a submarginal selvage. RV anteriorly with submarginal inner list, posteriorly with one inner list and a marginal selvage. A2 with natatory setae well-developed, reaching well beyond the end claws. T1 in female with two short setae a; seta d present in female, absent in male; setae b absent in both sexes. T2 with one short seta $\mathrm{d} 2$, seta $\mathrm{d} 1$ absent. T3 distally with incompletely developed pincer organ, fourth segment fused with third segment. CR in female with cylindrical base.

\section{Differential diagnosis}

Brasilodopsis gen. nov. belongs to the cypridopsine genera where the LV overlaps the RV; only six other genera belong to that group (see Table 1). The new genus differs from Austrocypridopsis McKenzie, 1982, Cavernocypris Hartmann, 1964 and Pseudocypridopsis Karanovic, 1999 by the long natatory setae on the A2 (short to very short in the other three genera). It further differs from Austrocypridopsis in the shape of the base of the CR, (triangular in Austrocypridopsis, cylindrical in Brasilodopsis gen. nov.) and in the shape of the valves in lateral view (rectangular in Austrocypridopsis). Cavernocypris also has a triangular base of the CR and furthermore lacks all inner lists and selvages on both valves, while the $\mathrm{T} 1$ has a seta $\mathrm{b}$ (missing in Brasilodopsis gen. nov.). Pseudocypridopsis also lacks inner lists and 
Table 1. Present list of tribes and genera in the subfamily Cypridopsinae Kaufmann, 1900. New tribe and new genera here described are in bold.

\begin{tabular}{l}
\hline Tribe Cypridopsini Kaufmann, 1900 \\
Genera with species with RV overlapping LV \\
Bryocypris Røen, 1956 \\
Kapcypridopsis McKenzie, 1977 \\
Klieopsis Martens et al., 1991 \\
Martenscypridopsis Karanovic \& Pesce, 2000 \\
Plesiocypridopsis Rome, 1965 \\
Sarscypridopsis McKenzie, 1977 \\
Siamopsis Savatenalinton, 2017 \\
Tanganyikacypridopsis Martens, 1985 \\
Thermopsis Külköylüoğlu et al., 2003 \\
Genera with species with LV overlapping RV \\
Austrocypridopsis McKenzie, 1982 \\
Brasilodopsis gen. nov. \\
Cavernocypris Hartmann, 1964 \\
Cypridopsis Brady, 1867 \\
Neocypridopsis Klie, 1940 \\
Pseudocypridopsis Karanovic, 1999 \\
Tungucypridopsis Victor, 1983 \\
Tribe Paranadopsinae trib. nov. \\
Paranadopsis gen. nov. \\
Tribe Potamocypridini Ghetti \& McKenzie, 1981 \\
Potamocypris Brady, 1870 \\
Tribe Zonocypridini Higuti \& Martens, 2012 \\
Cabelodopsis Higuti \& Martens, 2012 \\
Thaicypridopsis Savatenalinton, 2018 \\
Zonocypris G.W. Müller, 1898 \\
\hline
\end{tabular}

selvages; while the CR is missing in both males and females. Brasilodopsis gen. nov. further differs from Cypridopsis s. str. Brady, 1867 by the general shape of the $\mathrm{Cp}$ (much broader in dorsal view in Cypridopsis), while the posteroventral inner list in the LV does not run (sub-)parallel to the valve margin in this latter genus (it does so in Brasilodopsis gen. nov.), while the anterior inner list in this valve runs less than halfway the anterior valve margin (all the way to the dorsal margin in Brasilodopsis gen. nov.). The base of the CR in Cypridopsis is triangular, while it is elongated in Brasilodopsis gen. nov. Neocypridopsis Klie, 1940 has a very different shape of the Cp (rather high and swollen in dorsal view), but more importantly has the fourth segment of the T3 separate from the third segment, much like in Candonidae. Tungucypridopsis Victor, 1983, finally, is ill-described which makes a comparison with the present new genus difficult. It appears to lack the inner lists on both valves, which are moreover much larger than in Brasilodopsis gen. nov. (0.6 mm versus $0.4 \mathrm{~mm}$ - see Table 2).

Cyprettadopsis Savatenalinton, 2020 (placed in a separate tribe by this author) has a similar valve shape, including inner lists, but has (incomplete) marginal septae and a series of large ventral pores along the outer lists, which are both absent in Brasilodopsis gen. nov., while the T3 also has a separate fourth segment (fused into an incomplete pincer in Brasilodopsis gen. nov.). 
ALMEIDA N.M. et al., Cypridopsinae (Crustacea, Ostracoda) from Brazil

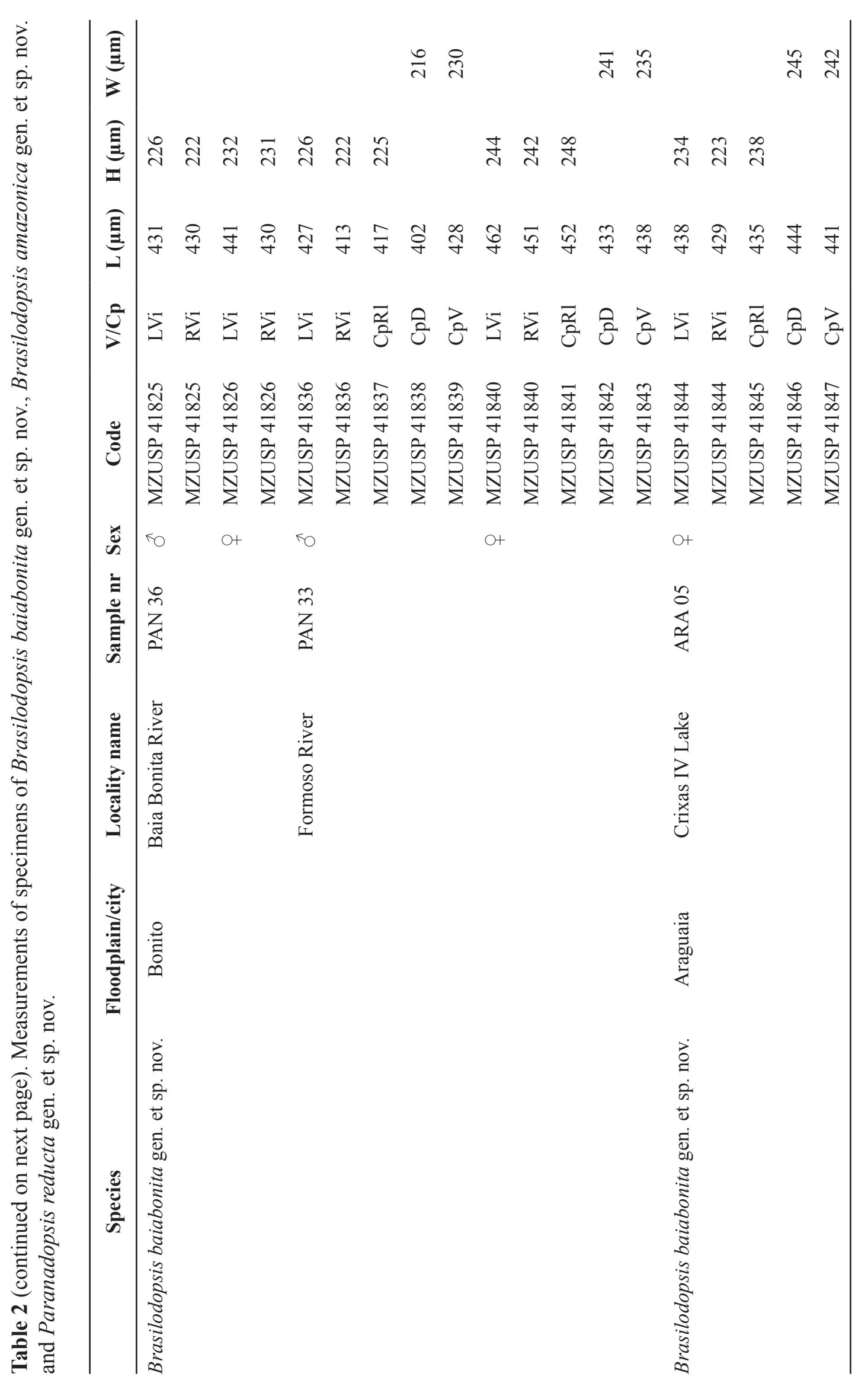




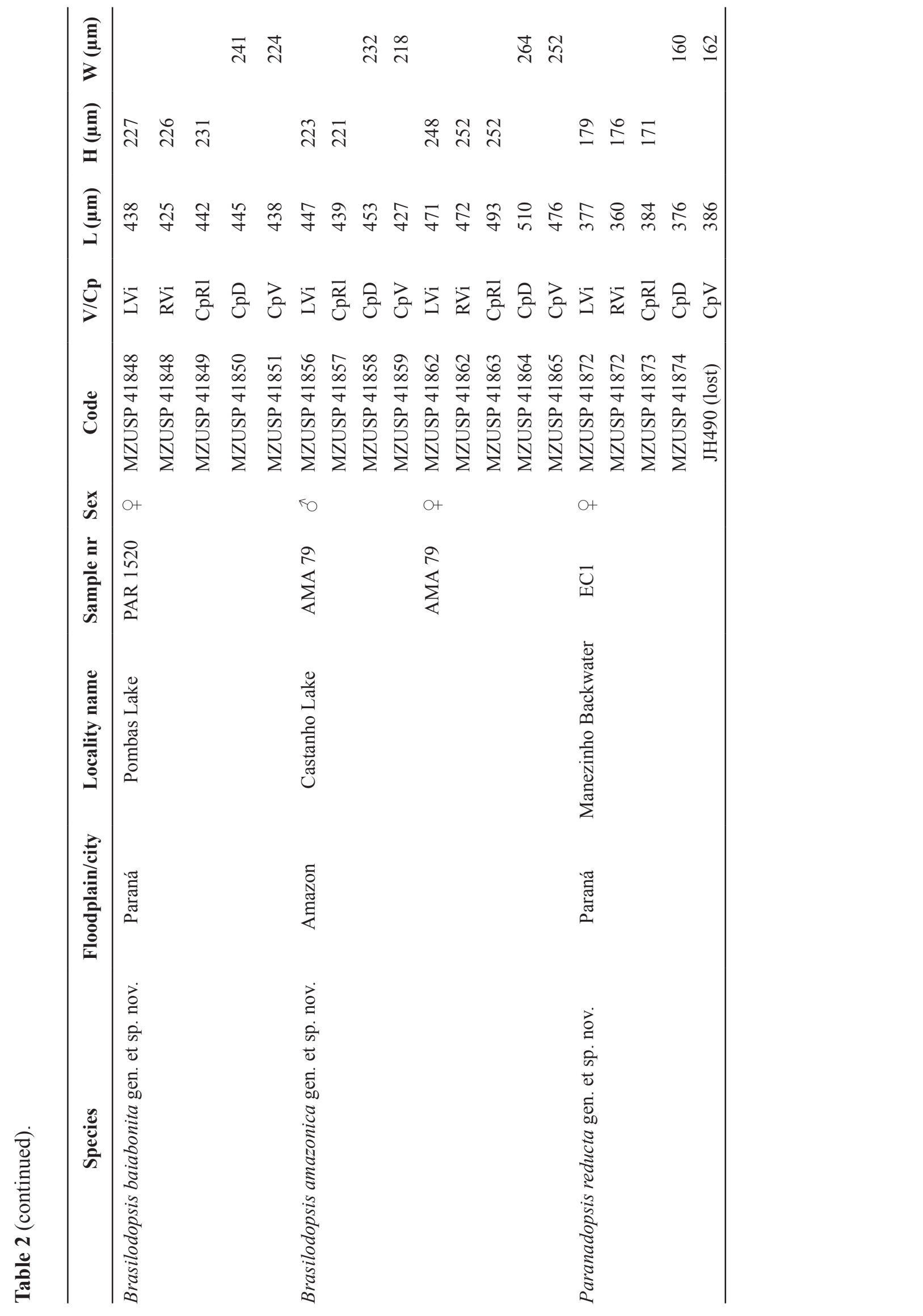




\section{Brasilodopsis baiabonita gen. et sp. nov. urn:1sid:zoobank.org:act:A3DE9437-5A51-4DA5-A186-470C197A8050}

Figs 2-12

"Cypridopsis" n.gen. 1 n.sp. - Higuti et al. 2009: 664, table 1; 2010: 267, table 2; 2017b: 7, table 2. Matsuda et al. 2015a: 326, table 1. - Pereira et al. 2017: 327, 329, table 2, fig. 5. - Conceição et al. 2018: 184, table 3.

“Cypridopsis" n. gen. n.sp. 2 - Campos et al. 2017: 38, table 2.

"Cypridopsis" n. gen. 2 n. sp. - Higuti et al. 2017a: 5, appendix 1.

"Cypridopsis" sp. 1 n.gen. n.sp. - Campos et al. 2018: 6, table 2; 2019: 375, table 1.

"Cypridopsis" n. gen. 1 n. sp. 1 - Higuti et al. 2020: 2, table S1.

\section{Diagnosis}

$\mathrm{Cp}$ in dorsal view with LV overlapping RV at anterior and posterior sides. LV and RV with welldeveloped anterior calcified inner lamella, with the greatest height in both valves situated in the middle of the dorsal margin. A2 with the natatory setae reaching beyond the tip of the end claws; seta $g$ absent. $\mathrm{T} 1$ with seta $\mathrm{d}$ absent in males, present in females. CR present only in female. Male prehensile palps asymmetrical. Rpp with first segment elongated and second segment with triangular lobe, Lpp with first segment elongated and second segment sickle shaped. Hemipenis with ventral lobe of ms rounded and ventral lobe of ls bird head-shaped and with two loops in the post-labyrinthal spermiduct.

\section{Etymology}

The species is named after its type locality, Baia Bonita River in the State of Mato Grosso do Sul (Brazil).

\section{Type material examined}

\section{Holotype}

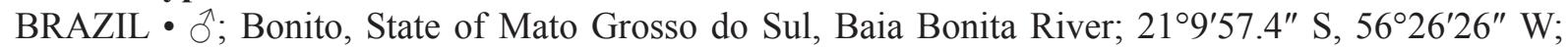
10 Jun. 2003; J. Higuti and K. Martens leg.; with soft parts dissected in glycerine in a sealed slide, valves stored dry in a micropalaeontological slide; sample PAN 36; MZUSP 41825.

\section{Allotype}

BRAZIL - '; Bonito, State of Mato Grosso do Sul, Baia Bonita River; 21 ${ }^{\circ} 9^{\prime} 57.4^{\prime \prime}$ S, 56 $26^{\prime} 26^{\prime \prime}$ W; 10 Jun. 2003; J. Higuti and K. Martens leg.; with soft parts dissected in glycerine in a sealed slide, valves stored dry in a micropalaeontological slide; sample PAN 36; MZUSP 41826.

\section{Paratypes}

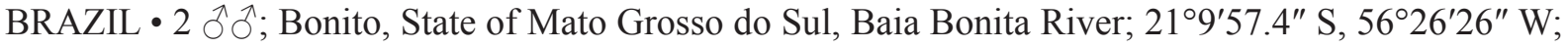
10 Jun. 2003; J. Higuti and K. Martens leg.; with soft parts dissected in glycerine in sealed slides, valves stored dry in micropalaeontological slides; sample PAN 36; MZUSP 41827, MZUSP 41828 • $1 \mathrm{~J}^{\top}$; Bonito, State of Mato Grosso do Sul, Baia Bonita River; 21 ${ }^{\circ} 9^{\prime} 57.4^{\prime \prime}$ S, 56 $26^{\prime} 26^{\prime \prime}$ W; 10 Jun. 2003; J. Higuti and K. Martens leg.; with soft parts dissected in glycerine in a sealed slide, LV stored dry in a micropalaeontological slide (RV lost); sample PAN 36; MZUSP 41829 • 2 ồ ; Bonito, State of Mato

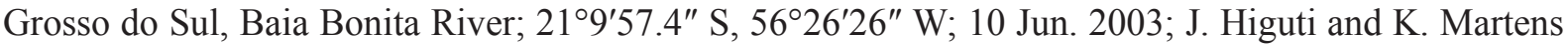
leg.; with soft parts dissected in glycerine in sealed slides, valves stored dry in micropalaeontological slides (both LV lost); sample PAN 36; MZUSP 41830, MZUSP 41831 • 3 q $q$; Bonito, State of Mato Grosso do Sul, Baia Bonita River; 21 ${ }^{\circ} 9^{\prime} 57.4^{\prime \prime}$ S, 56 26'26" W; 10 Jun. 2003; J. Higuti and K. Martens leg.; with soft parts dissected in glycerine in sealed slides, valves stored dry in micropalaeontological slides; sample PAN 36; MZUSP 41832 to MZUSP 41834 - 1 क; Bonito, State of Mato Grosso do Sul, Baia Bonita River; 21 ${ }^{\circ}{ }^{\prime} 57.4^{\prime \prime}$ S, 56 $26^{\prime} 26^{\prime \prime}$ W; 10 Jun. 2003; J. Higuti and K. Martens leg.; with soft parts dissected in glycerine in a sealed slide, RV stored dry in a micropalaeontological slide (LV lost); sample PAN 36; MZUSP 41835. 


\section{Other material illustrated}

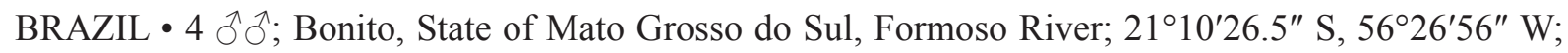
10 Jun. 2003; J. Higuti and K. Martens leg.; with valves and carapaces stored dry in micropalaeontological slides after use for SEM; sample PAN 33; MZUSP 41836 to MZUSP $41839 \bullet 4$ 우; Bonito, State of Mato Grosso do Sul, Formoso River; $2^{\circ} 10^{\prime 2} 26.5^{\prime \prime}$ S, 56 $26^{\prime} 56^{\prime \prime}$ W; 10 Jun. 2003; J. Higuti and K. Martens leg.; valves and carapaces stored dry in micropalaeontological slides after use for SEM; sample PAN 33; MZUSP 41840 to MZUSP 41843 • 1 क; Araguaia River floodplain, Crixas IV Lake; $13^{\circ} 20^{\prime} 37.5^{\prime \prime} \mathrm{S}$, $50^{\circ} 36^{\prime} 40^{\prime \prime}$ W; 2 Nov. 2011; J. Higuti leg.; with soft parts dissected in glycerine in a sealed slide, valves stored dry in a micropalaeontological slide after use for SEM; sample ARA 05; MZUSP $41844 \cdot 3$ q $O$; Araguaia River floodplain, Crixas IV Lake; 1320'37.5" S, 50³6'40" W; 2 Nov. 2011; J. Higuti leg.; carapaces stored dry in micropalaeontological slides after use for SEM; sample ARA 05; MZUSP 41845 to MZUSP 41847 • 1 o; Upper Paraná River floodplain, Pombas Lake; $22^{\circ} 47^{\prime} 56.8^{\prime \prime}$ S, 53⒉ $1^{\prime} 36.6^{\prime \prime} \mathrm{W}$; 22 Mar. 2018; J. Higuti, K. Martens and students leg.; with soft parts dissected in glycerine in a sealed slide, valves stored dry in a micropalaeontological slide after use for SEM; sample PAR 1520; MZUSP 41848 • 3 우; Upper Paraná River floodplain, Pombas Lake; 2247'56.8” S, 53²1'36.6" W; 22 Mar. 2018; J. Higuti, K. Martens and students leg.; carapaces stored dry in micropalaeontological slides after use for SEM; sample PAR 1520; MZUSP 41849 to MZUSP 41851.

\section{Other material examined}

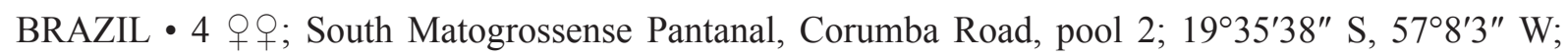
4 Jun. 2003; J. Higuti, K. Martens and K.F. Roche leg.; UEM-PAN 14; JH326 to JH329 • 3 o 9 ; South

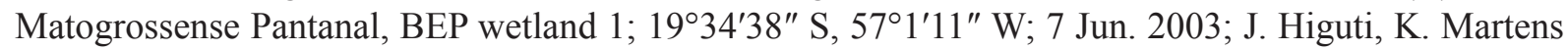
and K.F. Roche leg.; UEM-PAN 26; JH540, JH541, NA028 • 1 ㅇ, male specimen subsequently lost; South Matogrossense Pantanal, Miranda I River; $19^{\circ} 25^{\prime} 38.2^{\prime \prime}$ S, 57 $18^{\prime} 58.4^{\prime \prime}$ W; 23 Aug. 2011; L.F.M. Velho and L.C. Rodrigues leg.; UEM-PAN 63; NA030 • 6 우; South Matogrossense Pantanal, Miranda III River; 19²6'23.1" S, 57¹8'21.4" W; 23 Aug. 2011; L.F.M. Velho and L.C. Rodrigues leg.; UEMPAN 69; JH1060 to JH1065 • 1 क ; South Matogrossense Pantanal, Corumba Road, lake 1; 19³5'33" S, 57 ${ }^{\circ}{ }^{\prime} 19^{\prime \prime}$ W; 4 Jun. 2003; J. Higuti, K. Martens and K.F. Roche leg.; UEM-PAN 12; JH338 • 3 q ; Araguaia River floodplain, Comprido II Lake; $12^{\circ} 51^{\prime} 8.8^{\prime \prime}$ S, 50³4'4.8" W; 12 Mar. 2012; J. Higuti and K. Martens leg.; UEM-ARA 99; JH1479 to JH1481 • 4 우; Upper Paraná River floodplain, Caracu

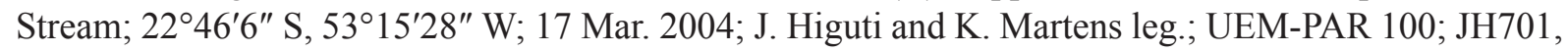
KM3453 to KM3455.

\section{Measurements of illustrated specimens}

See Table 2.

\section{Description}

\section{Male}

LVi (Figs 2A, C-D, 3A, C-D) with well-developed anterior calcified inner lamella, posterior calcified inner lamella narrow; a well-developed inner list running along and parallel to anterior, ventral and posterior valve margin, largely inwardly displaced anteriorly and posteriorly; anterior inner list running almost to the dorsal margin, posterior inner list elevated and running to the dorsal margin. Anteriorly with a submarginal selvage.

RVi (Figs 2B, E-F, 3B, E-F) with well-developed anterior calcified inner lamella, posterior calcified inner lamella narrow; short anteroventral trace of an inner list and posteroventrally with an elevated inwardly displaced inner list and a submarginal selvage, both running parallel to the valve margin.

Greatest height in both valves situated in the middle of the dorsal margin, indicated by a blunt corner. 
CpRl (Fig. 3G) with a triangular shape, with greatest height in the middle. $\mathrm{CpD}$ (Fig. 3H) external surface sparsely set with shallow pits and short setae and CpV (Fig. 3I) sub-ovate, with greatest width slightly behind the middle; anterior margin more pointed, posterior margin more rounded; LV overlapping RV along anterior, ventral and posterior margins, with an extended flap in the middle of the ventral side.

A1 (Fig. 4A) with seven segments. First segment large, ventrally with two long apical hirsute setae; dorsally with one short subapical hirsute seta, and with small Wouter's organ (Wo). Second segment subquadrate, with one short dorsal seta and a small ventral Rome organ (R). Third segment with two apical setae (the shorter ventral seta almost reaching the tip of the fourth segment; the longer dorsal seta slightly shorter than the length of the fifth segment). Fourth segment with three apical setae, two long dorsal ones, and one ventral seta, the latter slightly shorter than the length of the fifth segment. Fifth segment with three apical setae, two long dorsal setae and one short ventral seta, the latter reaching half the length of the terminal segment. Sixth segment with four long apical setae. Terminal segment with two unequally long setae, aesthetasc Ya and one shorter seta, the latter almost the same length of the aesthetasc Ya.

A2 (Fig. 4C-D) with protopodite, exopodite and three-segmented endopodite. Protopodite ventrally with three setae: two unequal but short setae, one long apical seta reaching beyond the tip of the terminal segment. Exopodite reduced to a small plate with one long seta (reaching beyond the tip of the terminal segment) and two sub-equal short setae. First endopodal segment ventrally with aestethasc Y (more than $1 / 3$ of the length of this segment), one long hirsute ventral seta (reaching beyond the tip of the terminal segment), and five natatory setae, reaching beyond the tip of the end claws, and one short accompanying seta, about $1 / 2$ of the length of the second endopodal segment. Second endopodal segment with two unequal but long dorsal setae, one short hirsute ventral seta $t$; apically with three claws ( $G 1$, G2, z1) and three setae (G3, z2, z3). Terminal segment (Fig. 4D) with two claws, one long (GM) and one short $(\mathrm{Gm})$ and one aesthetasc y3 with accompanying seta (slightly longer than the aesthetasc y3). Seta $g$ absent.

Rake-like organ (Fig. 4B) stout, solid, T-shaped, with seven apical teeth.

Md-palp (Fig. 5B) with four segments. First segment with two long plumose setae ( $\mathrm{S}_{1}$ and $\left.\mathrm{S}_{2}\right)$, one long smooth seta and one short smooth seta $\alpha$. Second segment with three dorsal setae (two long and one shorter, ca $2 / 3$ the length of the two longer ones); ventrally with one hirsute seta $\beta$ and four long setae (three equally long, and one slightly shorter). Third segment with three groups of setae: dorsally one group of three unequal but long setae; laterally with one hirsute and stout apical seta $\gamma$ and three smooth setae; ventrally with three unequal shorter setae. Terminal segment with three claws and three setae.

Md-coxa (Fig. 5A) elongated, dorsally with a short seta, and with strong and apical teeth, interspaced with some setae.

Mx1 (Fig. 5C-chaetotaxy not complete) consisting of three masticatory lobes (endites), a two-segmented palp and a large branchial plate (not illustrated). Branchial plate elongated, with ca 16 respiratory rays, some quite short, others longer. First segment of palp with five setae (four unequal but long setae and one short subapical seta, about $1 / 4$ of the longest one). Terminal segment of palp ca twice as long as basal width, apically with two claw-like setae and two setae. Third endite apically with two serrated claws and several setae. First endite at its base with two unequal setae and apically with ca five unequal, sideways directed bristles.

T1 (Fig. 6A-C) protopodite apically with a group of eight hirsute setae, and two short setae a inserted in the middle, seta d absent. Endopodites (Fig. 6B-C) asymmetrical prehensile palps: Rpp (Fig. 6B) with first segment elongated, with two subapical spines, second segment with triangular lobe, with uneven dorsal and straight distal margin. Lpp (Fig. 6C) with first segment elongated, with two sub-apical spines, second segment sickle-shaped, with swollen basis and bluntly pointed distal part. 


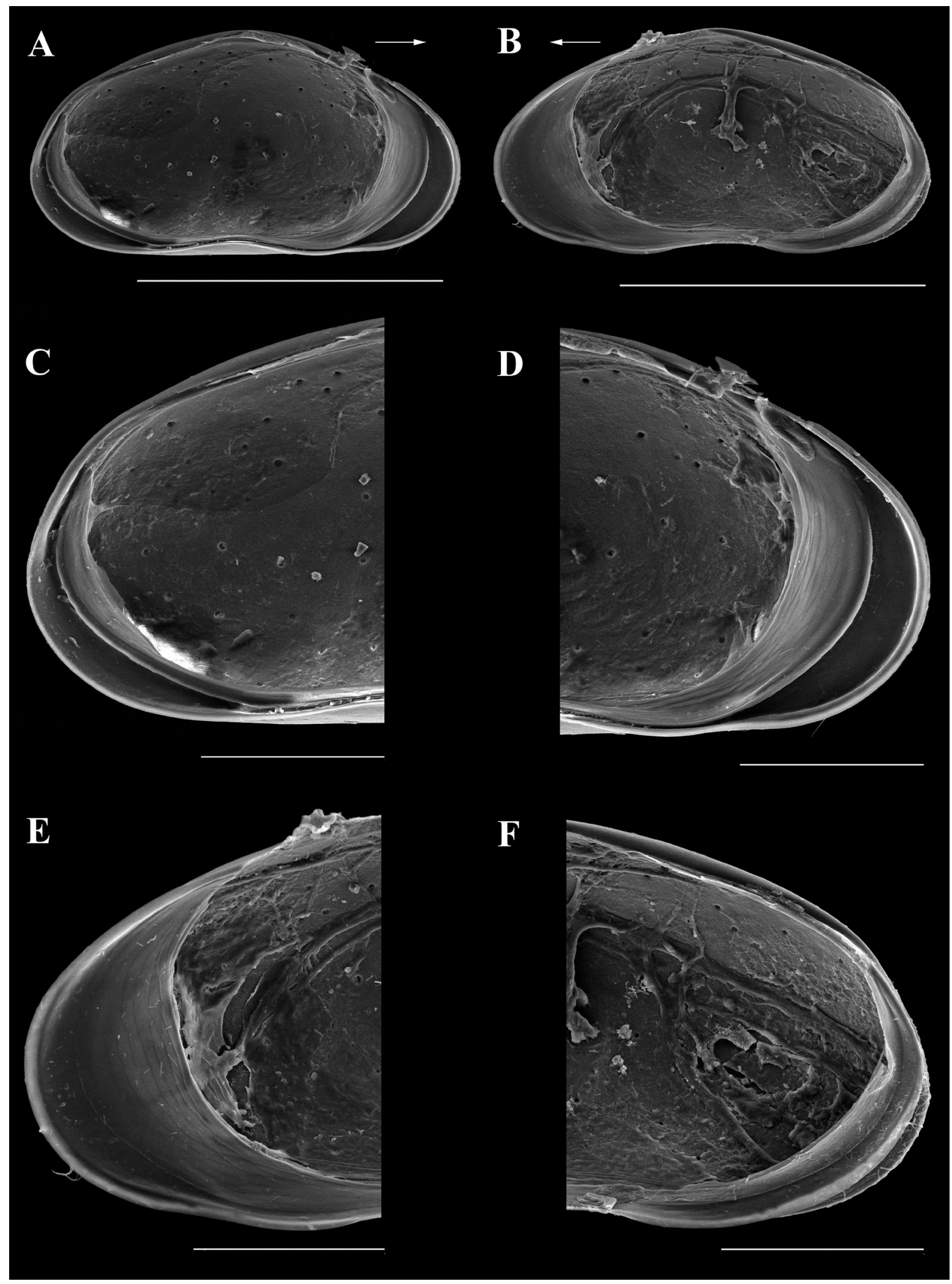

Fig. 2. Brasilodopsis baiabonita gen. et sp. nov. from Bonito, State of Mato Grosso do Sul, ô. A. LVi (MZUSP 41825). B. RVi (MZUSP 41825). C. LVi, detail of posterior part (MZUSP 41825). D. LVi, detail of anterior part (MZUSP 41825). E. RVi, detail of anterior part (MZUSP 41825). F. RVi, detail of posterior part (MZUSP 41825). Scale bars: A-B $=300 \mu \mathrm{m}$; $C-F=100 \mu \mathrm{m}$. 

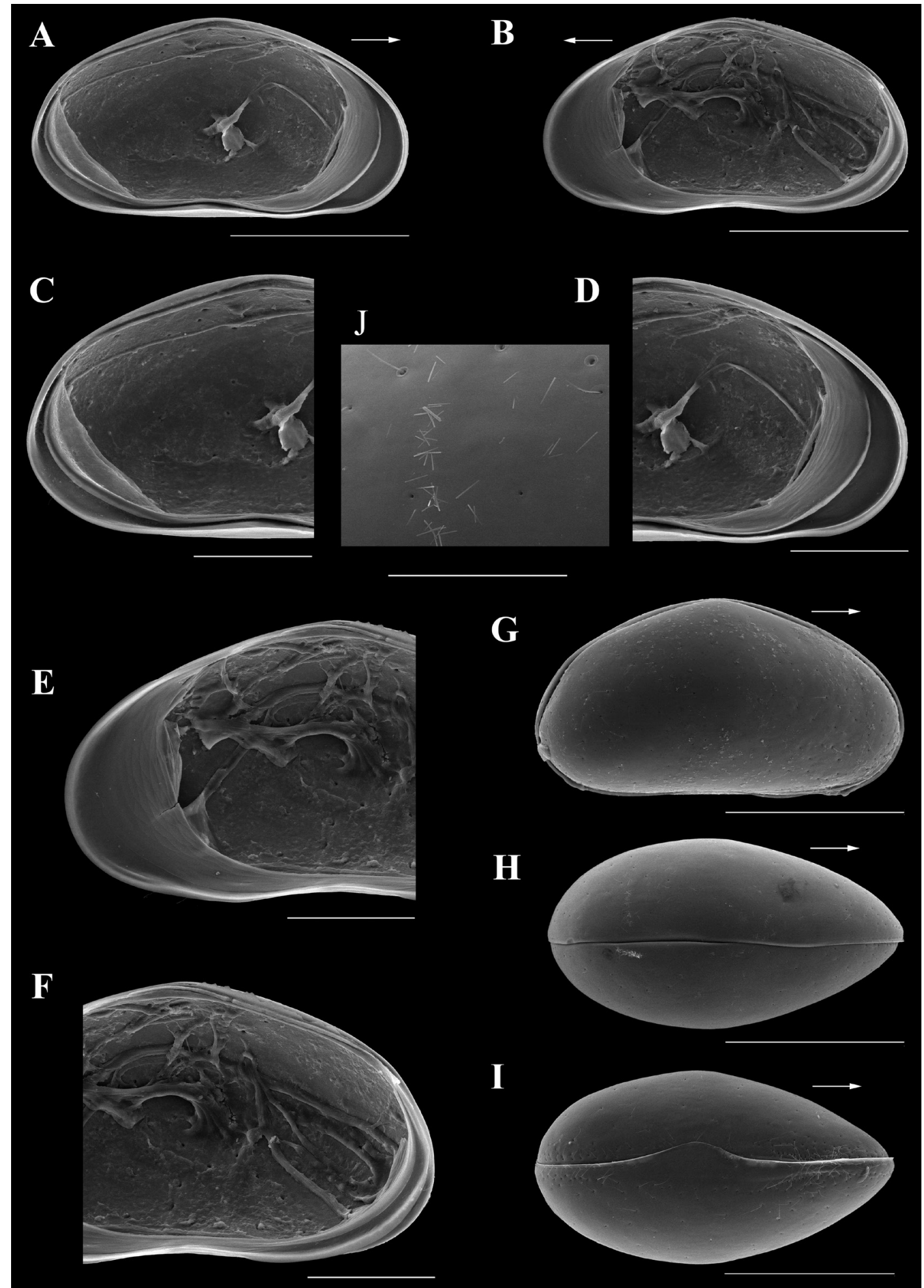

Fig. 3. Brasilodopsis baiabonita gen. et sp. nov. from Bonito, State of Mato Grosso do Sul, §̂. A. LVi (MZUSP 41836). B. RVi (MZUSP 41836). C. LVi, detail of posterior part (MZUSP 41836). D. LVi, detail of anterior part (MZUSP 41836). E. RVi, detail of anterior part (MZUSP 41836). F. RVi, detail of posterior part (MZUSP 41836). G. CpRl (MZUSP 41837). H. CpD (MZUSP 41838). I. CpV (MZUSP 41839). J. CpD, detail of pores and setae (MZUSP 41838). Scale bars: A-B, G-I $=300 \mu \mathrm{m}$; $\mathrm{C}-\mathrm{F}=$ $100 \mu \mathrm{m} ; \mathrm{J}=50 \mu \mathrm{m}$. 


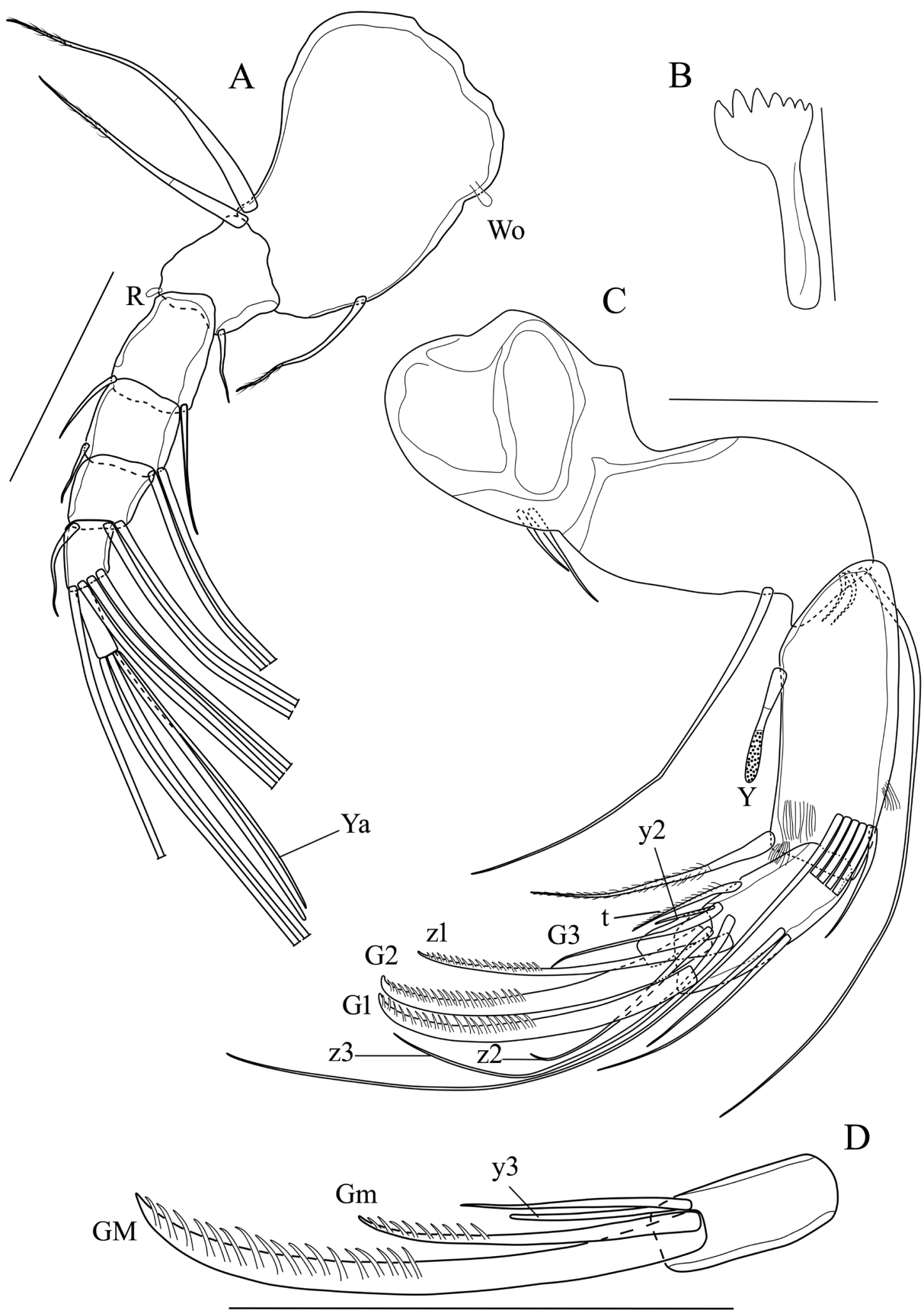

Fig. 4. Brasilodopsis baiabonita gen. et sp. nov. from Bonito, State of Mato Grosso do Sul, $\widehat{\partial}$. A. A1 (MZUSP 41825). B. Rake-like organ (MZUSP 41825). C. A2, without the terminal segment (MZUSP 41827). D. A2, terminal segment (MZUSP 41827). Abbreviations: see text and Material and methods. Scale bars: A, $\mathrm{C}-\mathrm{D}=50 \mu \mathrm{m} ; \mathrm{B}=20 \mu \mathrm{m}$. 

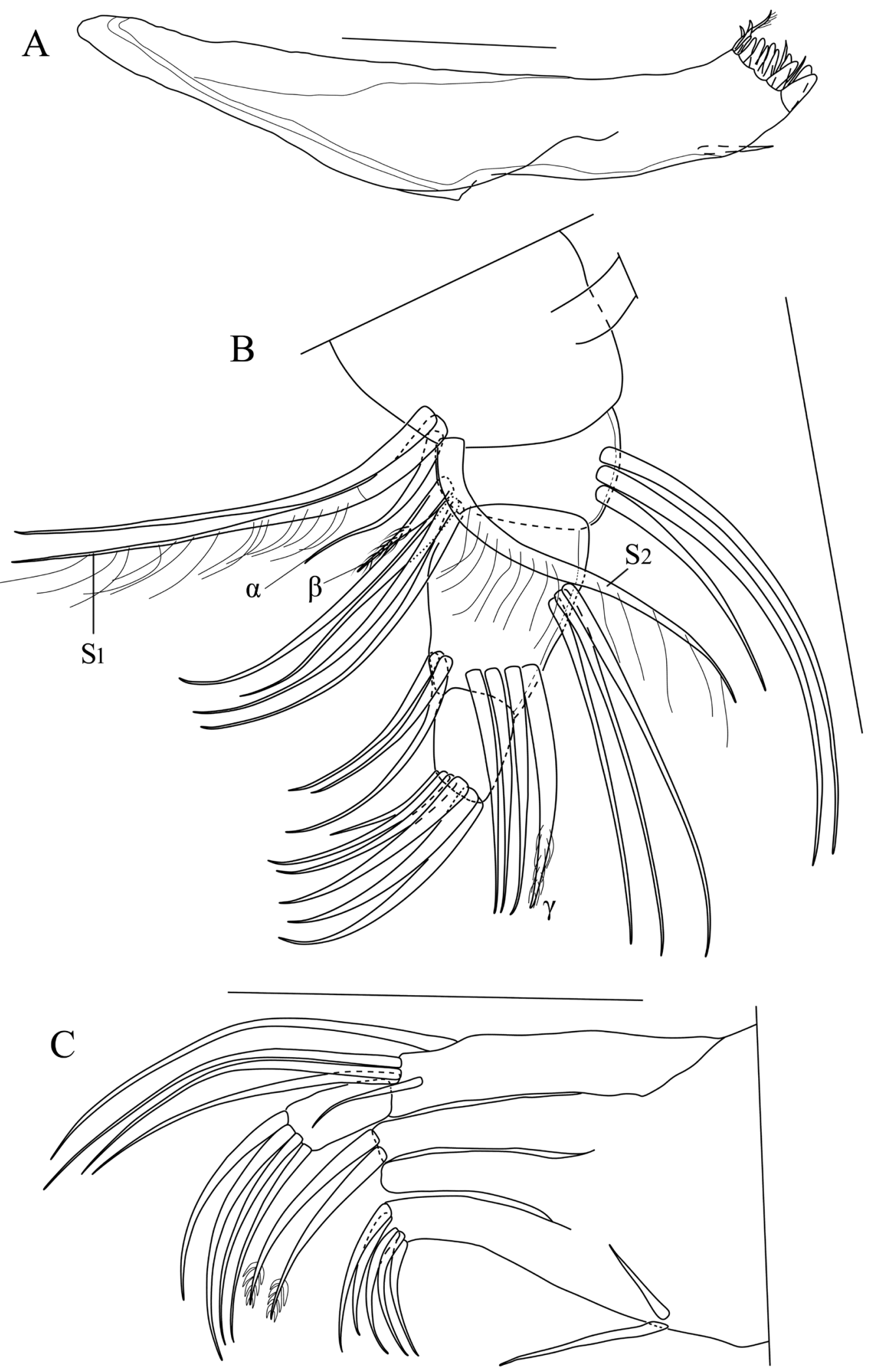

Fig. 5. Brasilodopsis baiabonita gen. et sp. nov. from Bonito, State of Mato Grosso do Sul, ô. A. Md (MZUSP 41827). B. Md-palp (MZUSP 41825). C. Mx1 (MZUSP 41825). Abbreviations: see text and Material and methods. Scale bars: A-C $=50 \mu \mathrm{m}$. 


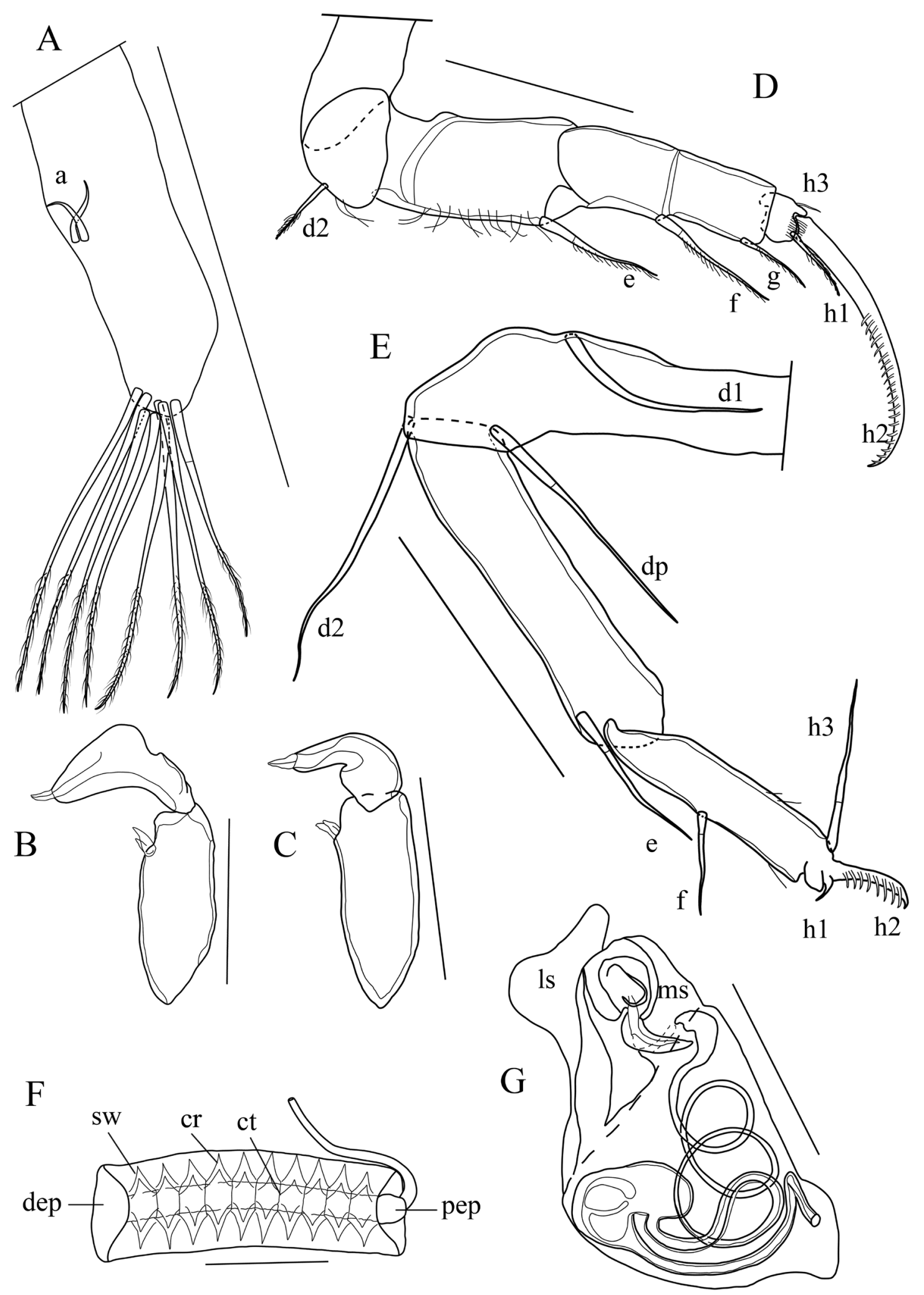

Fig. 6. Brasilodopsis baiabonita gen. et sp. nov. from Bonito, State of Mato Grosso do Sul, đ̃. A. T1 (MZUSP 41825). B. Rpp (MZUSP 41827). C. Lpp (MZUSP 41827). D. T2 (MZUSP 41825). E. T3 (MZUSP 41827). F. Zenker's organ (MZUSP 41827). G. Hemipenis (MZUSP 41827). Abbreviations: see text and Material and methods. Scale bars: $50 \mu \mathrm{m}$. 
T2 (Fig. 6D) with protopodite, a 'knee'-segment and four endopodite segments. Protopodal segment without seta d1. 'Knee'-segment with one short subapical seta d2. First endopodal segment with one apical hirsute seta e, reaching the tip of the second endopodal segment. Second endopodal segment with one apical hirsute seta $\mathrm{f}$, reaching beyond the tip of the terminal segment. Third endopodal segment with one subapical hirsute seta g, approximately half of the length of the seta f. Terminal segment with one apical serrated claw h2, one short hirsute subapical seta h1 and a very short seta h3.

T3 (Fig. 6E) with three segments. First segment with two unequal long (d2, dp) and one shorter setae d1. Second segment with one subapical seta e, reaching the middle of the third segment. Third segment medially with one seta $\mathrm{f}$, about $1 / 2$ the length of the third segment. Distal part of third segment with a pincer structure, one small spine-like structure (h1), one long subapical seta $h 3$, about twice of the length of the broad seta $\mathrm{h} 2$, the latter set with spine-like setulae.

Zenker's organ (Fig. 6F) about four times as long as wide, with ca $10 \mathrm{sw.}$

Hemipenis (Fig. 6G) with distal lobe of ms rounded, distal lobe of 1s bird head-shaped, with rounded margins, and a bluntly pointed distal beak.

\section{Female}

LVi (Figs 7A, C-D; 8A, C-D), RVi (Figs 7B, E-F; 8B, E-F), CpRl (Fig. 8G), CpD (Fig. 8H) and CpV (Fig. 8I) as in the male.

\section{A1, Rake-like organ, Md-coxa and Mx1 (not illustrated) as in the male.}

A2 (Fig. 9A-B) with protopodite, exopodite and three-segmented endopodite. Protopodite ventrally with three setae: two unequal but short setae, one long apical seta reaching beyond the tip of the terminal segment. Exopodite reduced to a small plate with one long seta (reaching beyond the tip of the terminal segment) and two sub-equal short setae. First endopodal segment ventrally with aestethasc Y (more than $1 / 3$ of the length of this segment), one long hirsute ventral seta (reaching beyond the tip of the terminal segment), and five natatory setae, reaching beyond the tip of the end claws, and one short accompanying seta, about $1 / 2$ of the length of the second endopodal segment. Second endopodal segment with two unequal, but long dorsal setae, four ventral setae $t$ (two unequal but long, one ca half of the length of the longest setae, and one short, approximately $1 / 4$ of longest setae); apically with three claws (G1, G2, G3) and three setae (z1, z2, z3). Terminal segment (Fig. 9B) with two claws, one long (GM) one short (Gm) and one aesthetasc $y 3$ with accompanying seta, slightly longer than y3. Seta $g$ absent.

T1 (Fig. 9C) Protopodite apically with a group of eight hirsute setae; two short setae a and one long seta d. Endopodite apically with three subequal long and plumose setae.

T2 (Fig. 10A) largely as in the male, with protopodite, a 'knee'-segment and four endopodite segments. Protopodal segment without seta d1. 'Knee' segment with one short subapical seta d2. First endopodal segment with one apical hirsute seta e, reaching the tip of the second endopodal segment. Second endopodal segment with one apical hirsute seta $f$, just reaching the tip of the fifth segment. Third endopodal segment with one subapical hirsute seta $g$, approximately $2 / 3$ of the length of the seta $f$. Terminal segment with one apical serrated claw h2, one short hirsute subapical seta h1 and a very short seta h3 (not visible here).

T3 (Fig. 10B) largely as in the male, with three segments. First segment with two unequal long (d2, dp) and one shorter setae d1. Second segment with one subapical seta e, reaching the middle of the third segment. Third segment medially with one seta $\mathrm{f}$, about $1 / 2$ the length of the third segment. Distal part of third segment with a pincer structure, one small spine-like structure (h1), one long subapical seta h3, about twice the length of the broad seta h2, the latter set with spine-like setulae.

CR (Fig. 10C) with cylindrical base, one subapical short seta and one long apical seta (ca 3 times the length of the base). 


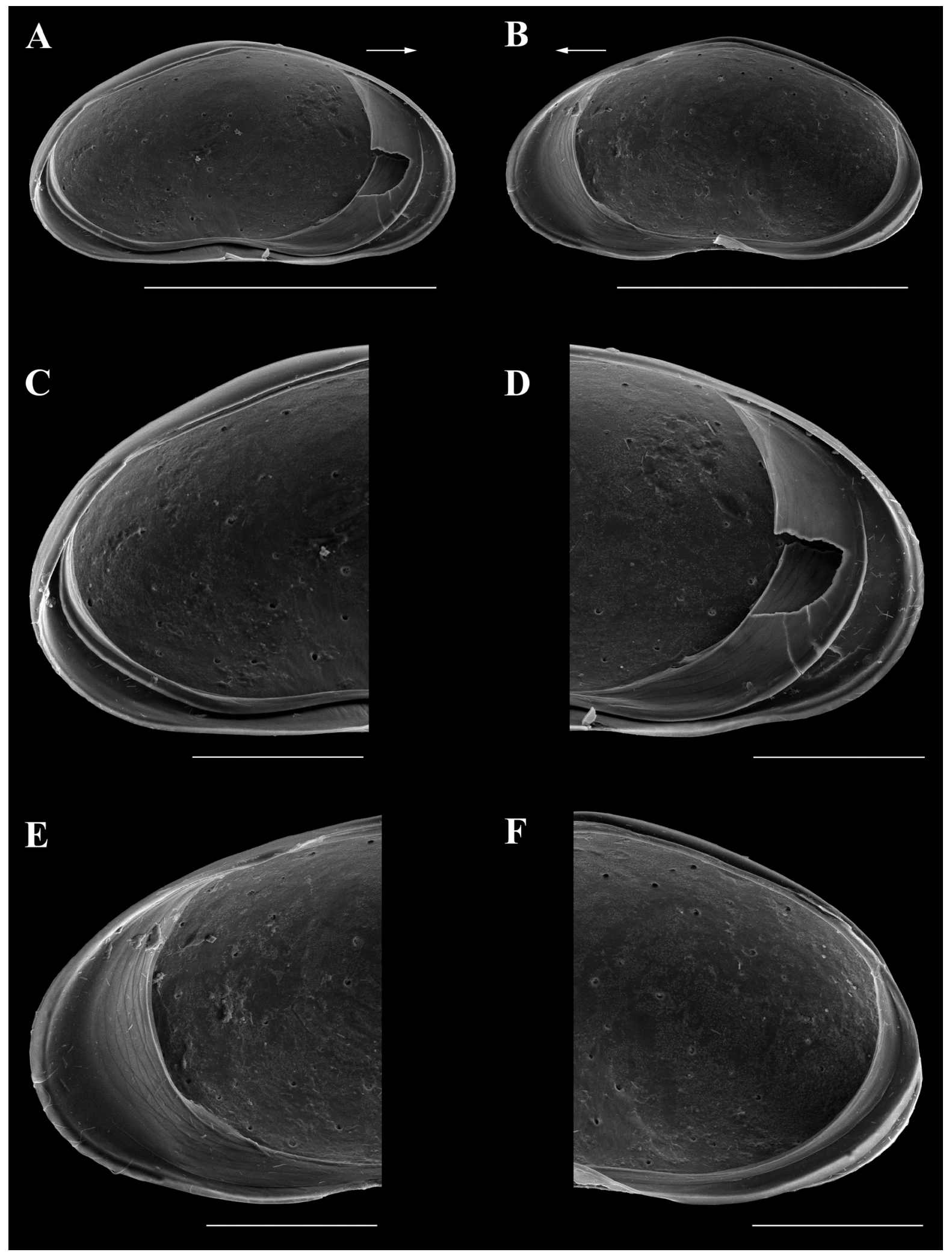

Fig. 7. Brasilodopsis baiabonita gen. et sp. nov. from Bonito, State of Mato Grosso do Sul, 9 . A. LVi (MZUSP 41826). B. RVi (MZUSP 41826). C. LVi, detail of posterior part (MZUSP 41826). D. LVi, detail of anterior part (MZUSP 41826). E. RVi, detail of anterior part (MZUSP 41826). F. RVi, detail of posterior part (MZUSP 41826). Scale bars: A-B $=300 \mu \mathrm{m}$; $C-F=100 \mu \mathrm{m}$. 


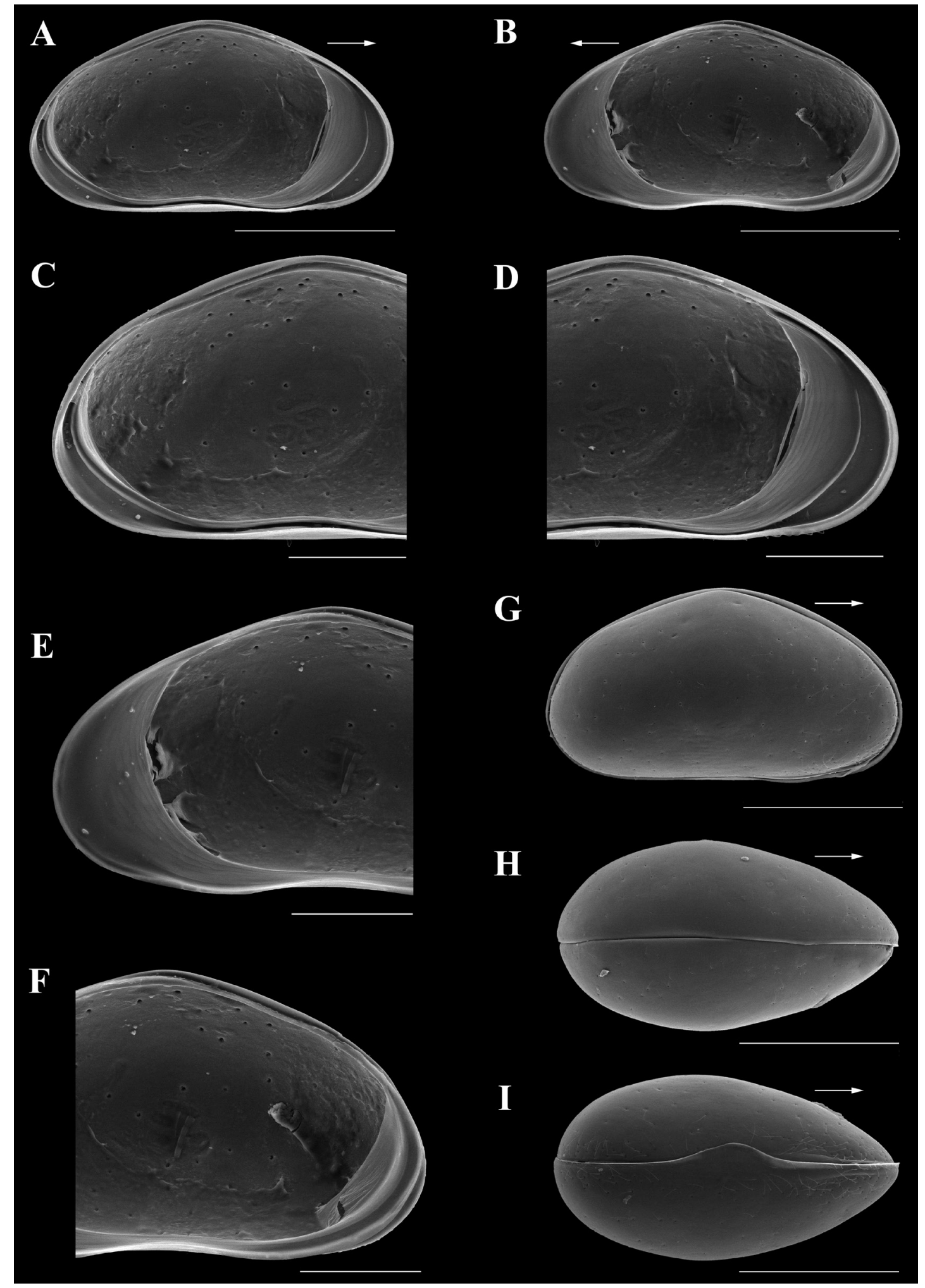

Fig. 8. Brasilodopsis baiabonita gen. et sp. nov. from Bonito, State of Mato Grosso do Sul, 9 . A. LVi (MZUSP 41840). B. RVi (MZUSP 41840). C. LVi, detail of posterior part (MZUSP 41840). D. LVi, detail of anterior part (MZUSP 41840). E. RVi, detail of anterior part (MZUSP 41840). F. RVi, detail of posterior part (MZUSP 41840). G. CpRl (MZUSP 41841). H. CpD (MZUSP 41842). I. CpV (MZUSP 41843). Scale bars: A-B, G-I $=300 \mu \mathrm{m} ; \mathrm{C}-\mathrm{F}=100 \mu \mathrm{m}$. 


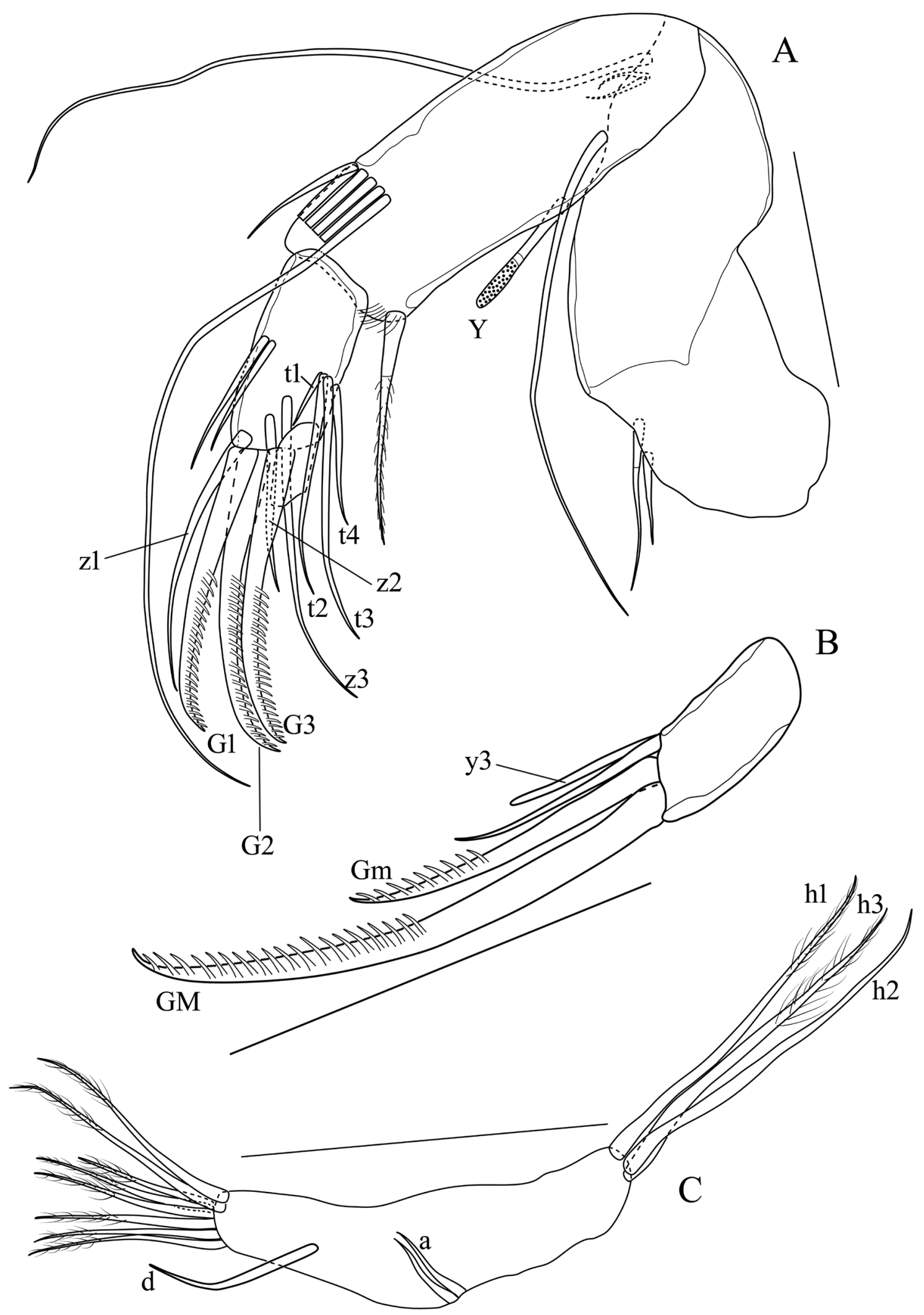

Fig. 9. Brasilodopsis baiabonita gen. et sp. nov. from Bonito, State of Mato Grosso do Sul, o. A. A2, without the terminal segment (MZUSP 41832). B. A2, terminal segment (MZUSP 41832). C. T1 (MZUSP 41826). Abbreviations: see text and Material and methods. Scale bars: $50 \mu \mathrm{m}$. 

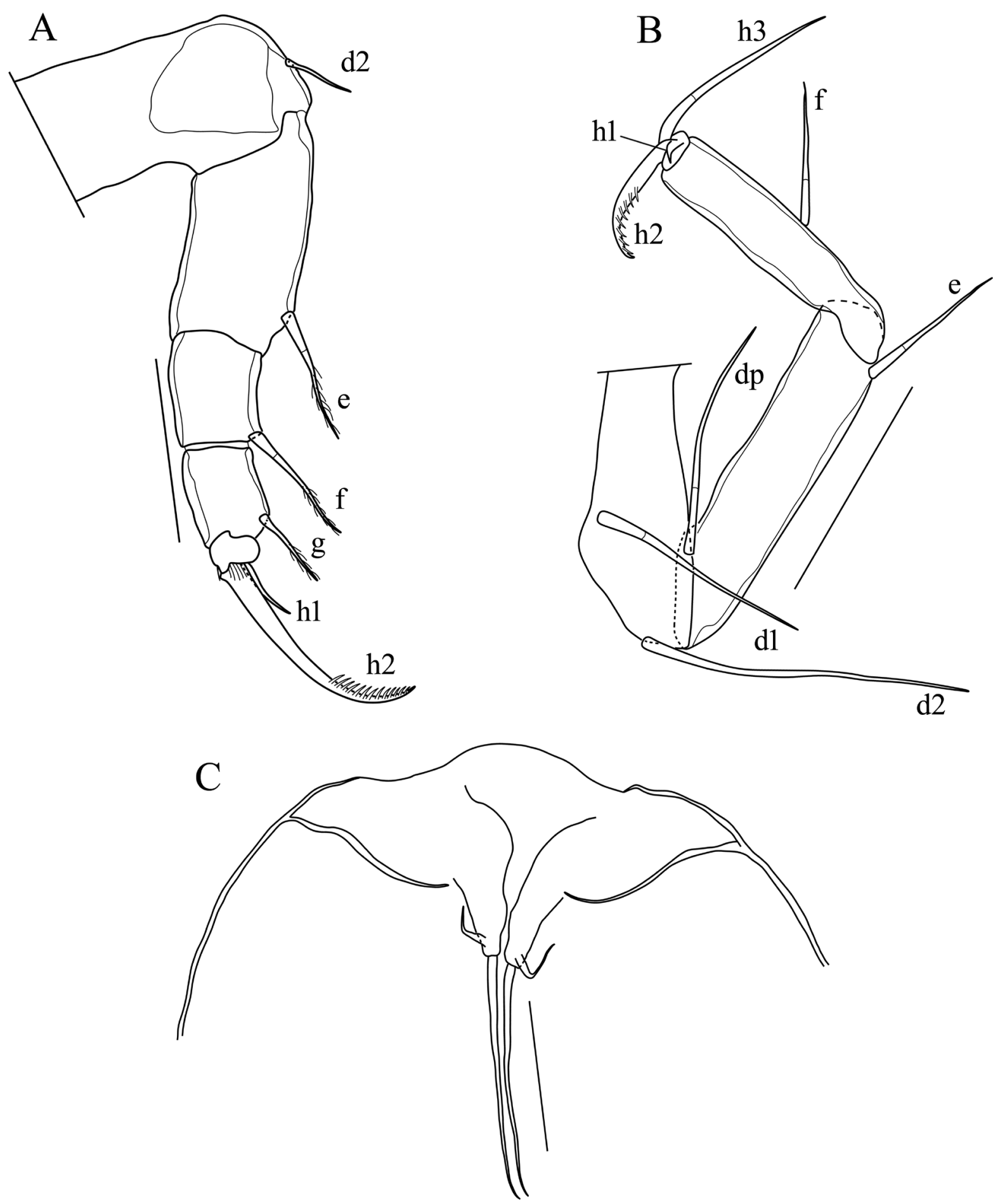

Fig. 10. Brasilodopsis baiabonita gen. et sp. nov. from Bonito, State of Mato Grosso do Sul, 9 . A. T2 (MZUSP 41832). B. T3 (MZUSP 41832). C. CR (MZUSP 41826). Abbreviations: see text and Material and methods. Scale bars: $50 \mu \mathrm{m}$. 

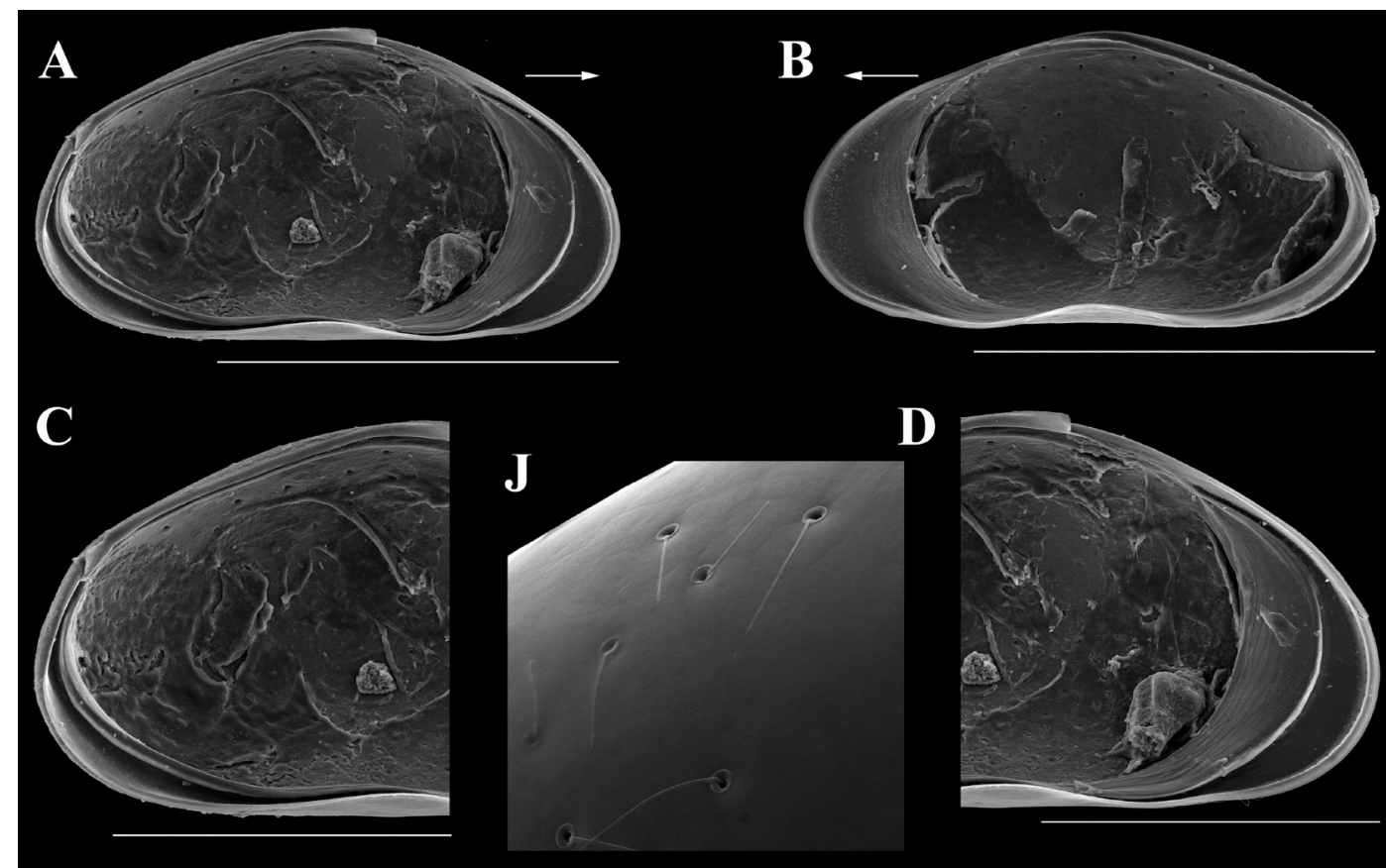

D
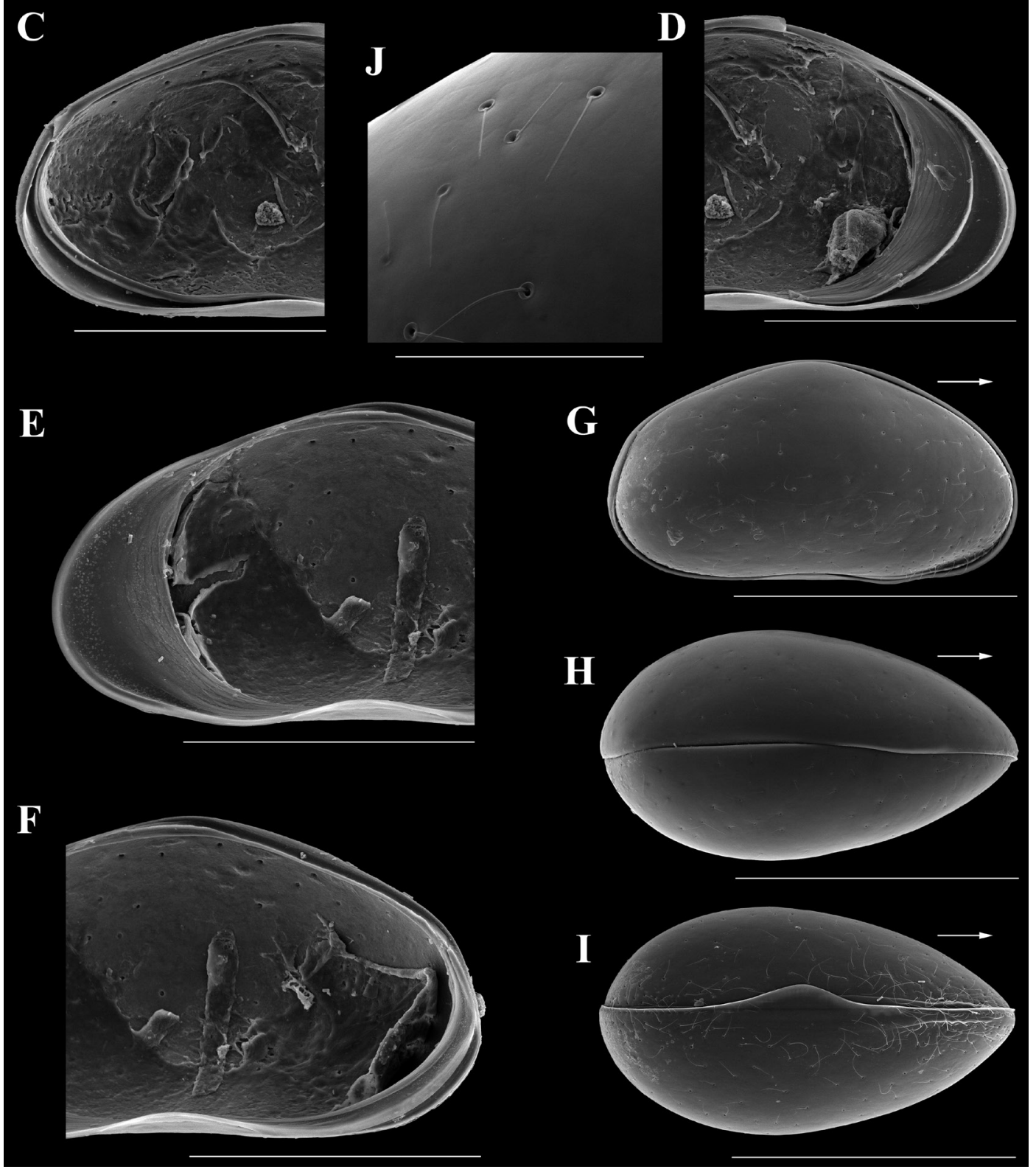

Fig. 11. Brasilodopsis baiabonita gen. et sp. nov. from Araguaia River floodplain, ․ . A. LVi (MZUSP 41844). B. RVi (MZUSP 41844). C. LVi, detail of posterior part (MZUSP 41844). D. LVi, detail of anterior part (MZUSP 41844). E. RVi, detail of anterior part (MZUSP 41844). F. RVi, detail of posterior part (MZUSP 41844). G. CpRl (MZUSP 41845). H. CpD (MZUSP 41846). I. CpV (MZUSP 41847). J. CpD, detail of Cp surface (MZUSP 41846). Scale bars: A-B, G-I = $300 \mu \mathrm{m}$; C-F $=200 \mu \mathrm{m} ; \mathrm{J}=$ $50 \mu \mathrm{m}$. 

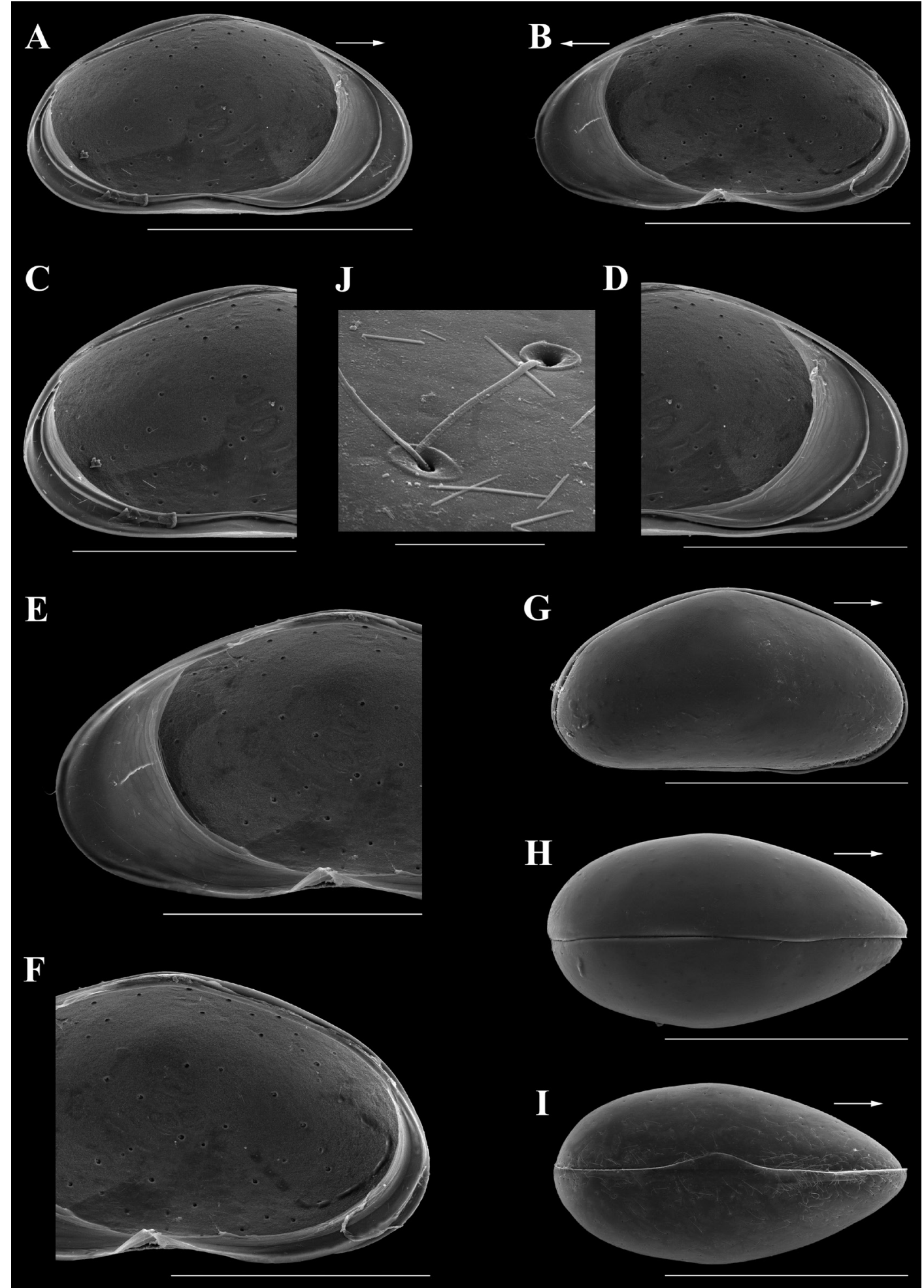

Fig. 12. Brasilodopsis baiabonita gen. et sp. nov. from Upper Paraná River floodplain, q. A. LVi (MZUSP 41848). B. RVi (MZUSP 41848). C. LVi, detail of posterior part (MZUSP 41848). D. LVi, detail of anterior part (MZUSP 41848). E. RVi, detail of anterior part (MZUSP 41848). F. RVi, detail of posterior part (MZUSP 41848). G. CpRl (MZUSP 41849). H. CpD (MZUSP 41850). I. CpV (MZUSP 41851). J. CpV, detail of Cp surface (MZUSP 41851). Scale bars: A-B, G-I = $300 \mu \mathrm{m}$; C-F $=200 \mu \mathrm{m} ; \mathrm{J}=10 \mu \mathrm{m}$. 
Table 3. Comparative morphology of the two new genera described in this paper.

\begin{tabular}{lccccccc}
\hline & $\begin{array}{c}\text { LV } \\
\text { inner } \\
\text { list }\end{array}$ & $\begin{array}{c}\text { RV } \\
\text { post. } \\
\text { inner } \\
\text { list }\end{array}$ & $\begin{array}{c}\text { A2 nat. } \\
\text { setae }\end{array}$ & $\begin{array}{c}\text { Mx1, setae } \\
\text { on } \\
\mathbf{1}^{\text {st }} \text { palp } \\
\text { segment }\end{array}$ & $\begin{array}{c}\text { T1, d1 } \\
\text { seta }\end{array}$ & $\begin{array}{c}\text { T1, d2 } \\
\text { seta }\end{array}$ & CR \\
\hline Brasilodopsis baiabonita gen. et sp. nov. & Strong & Present & Long & $4+1$ & Absent & Present & Flagellate \\
Brasilodopsis amazonica gen. et sp. nov. & Strong & Present & Long & $4+1$ & Absent & Present & Flagellate \\
Paranadopsis reducta gen. et sp. nov. & Weak & Absent & Absent & 2 & Absent & Absent & Absent \\
\hline
\end{tabular}

\section{Differential diagnosis}

Cp sub-ovate, slightly higher and with blunt point in the middle of the dorsal margin (smoothly rounded in B. amazonica gen. et sp. nov.). Posterior inner list in LV more robust than in B. amazonica gen. et sp. nov. (see Table 3). External valve surface smooth, with sparse setae and pores in Brasilodopsis baiabonita gen. et sp. nov., (densely set with rimmed pores in shallow pits in B. amazonica gen. et sp. nov.). Hemipenis outline similar in both species, but distal segments of prehensile palps with subtle differences.

\section{Ecology and distribution}

Brasilodopsis baiabonita gen. et sp. nov. was recorded from three tropical Brazilian floodplains (Araguaia, Pantanal and Paraná), associated with different species of macrophytes and sediment (mud, sand). The water temperature ranged between 18.5 and $32.6^{\circ} \mathrm{C}$. The $\mathrm{pH}$ ranged from acid (5) to basic (8.9). The range of electrical conductivity was between 14 and $415 \mu{\mathrm{S} . \mathrm{cm}^{-1}}^{-1}$ and the values of dissolved oxygen varied from 0.1 to $7.8 \mathrm{mg} . \mathrm{L}^{-1}$ (see Table 4 ).

\section{Remarks}

In order to show that valve and $\mathrm{Cp}$ morphologies are similar in all three floodplains, we here also illustrate this in Figs 11 (Araguaia) and 12 (Paraná), albeit for all-female populations only.

Brasilodopsis amazonica gen. et sp. nov.

urn:1sid:zoobank.org:act:52B493C0-AC19-49EB-95BD-77E4805A9957

Figs $13-17$

“Cypridopsis" n. gen. 1 n.sp. - Higuti \& Martens 2016: appendix 1.

\section{Diagnosis}

LV and RV with well-developed anterior calcified inner lamella, with greatest height in both valves situated in the middle of the smoothly curved dorsal margin. A2 with the natatory setae reaching beyond the tip of the end claws and seta $\mathrm{g}$ absent. Valve surface densely set with rimmed pores in shallow pits. $\mathrm{T} 1$ with seta $d$ present in female, absent in male. CR present in female only. Male prehensile palps asymmetrical; Rpp with first segment rather stout and second segment with triangular lobe; Lpp with first segment elongated and second segment sickle shaped. Hemipenis with ventral lobe of ms rounded and ventral lobe of ls bird head-shaped; with two loops in post-labyrinthal spermiduct. 


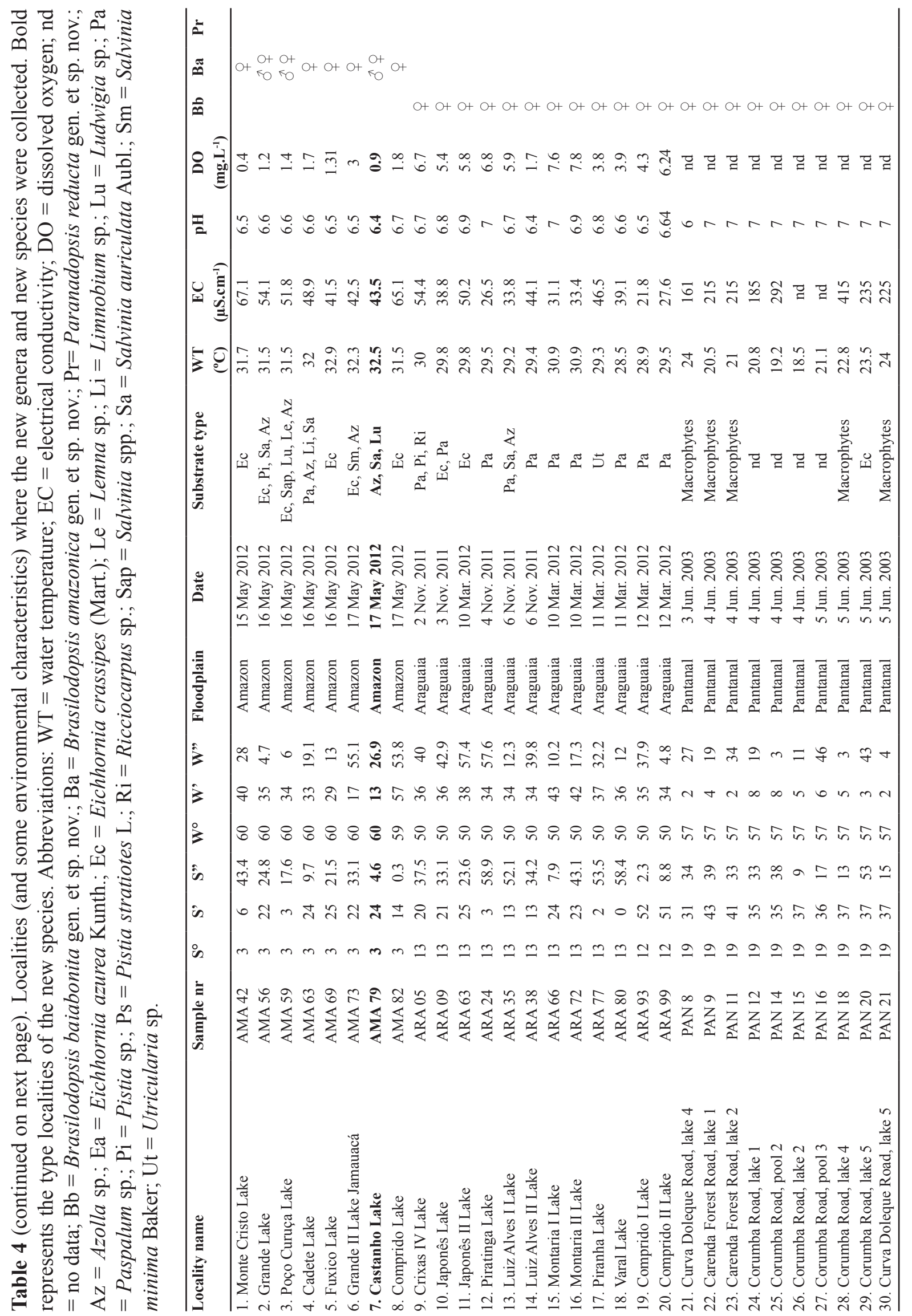




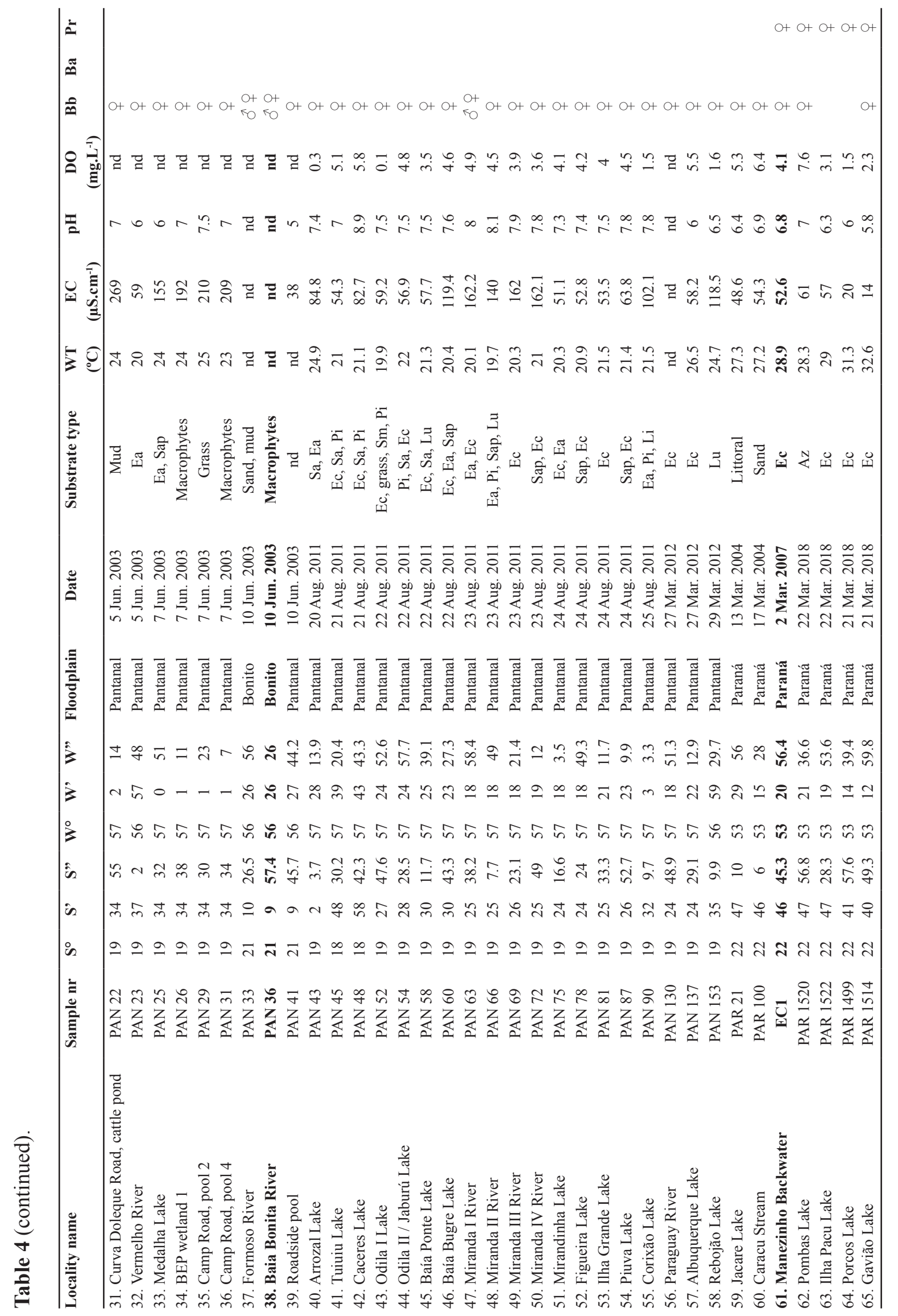




\title{
Etymology
}

The species is named after the area from which it is here described, namely Amazonia, Brazil.

\section{Material examined}

\section{Holotype}

BRAZIL • o'; Amazon River floodplain, Castanho Lake; 3²4'4.6" S, 60¹3'26.9” W; 17 May 2012; J. Higuti leg.; with soft parts dissected in glycerine in a sealed slide, valves stored dry in a micropalaeontological slide; sample AMA 79; MZUSP 41852.

\begin{abstract}
Allotype
BRAZIL • O; Amazon River floodplain, Castanho Lake; 3²4'4.6" S, 60¹3'26.9" W; 17 May 2012; J. Higuti leg.; with soft parts dissected in glycerine in a sealed slide, valves stored dry in a micropalaeontological slide; sample AMA 79; MZUSP 41853.

\section{Paratypes}

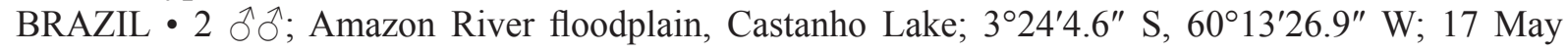
2012; J. Higuti leg.; with soft parts dissected in glycerine in sealed slides, LV and RV lost; sample AMA 79; MZUSP 41854, MZUSP 41855 • 1 ○े; Amazon River floodplain, Castanho Lake; 324'4. $6^{\prime \prime}$ S, 60²'13'26." W; 17 May 2012; J. Higuti leg.; with soft parts dissected in glycerine in a sealed slide, LV stored dry in a micropalaeontological slide after use for SEM; sample AMA 79; MZUSP 41856 •

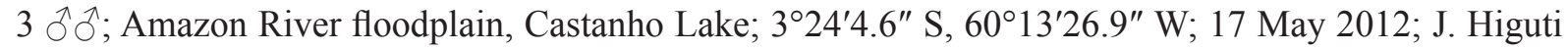
leg.; carapaces stored dry in micropalaeontological slides after use for SEM; sample AMA 79; MZUSP 41857 to MZUSP 41859 • 1 q; Amazon River floodplain, Castanho Lake; 3²4'4.6" S, 60 $13^{\prime 2} 26.9^{\prime \prime} \mathrm{W}$; 17 May 2012; J. Higuti leg.; with soft parts dissected in glycerine in a sealed slide, both LV and RV lost; sample AMA 79; MZUSP 41861 • 1 क; Amazon River floodplain, Castanho Lake; 3²4'4.6" S, 60¹3'26.9" W; 17 May 2012; J. Higuti leg.; with soft parts dissected in glycerine in sealed slides, valves stored dry in micropalaeontological slides; sample AMA 79; MZUSP 41860 • 1 \%; Amazon River floodplain, Castanho Lake; 324'4.6" S, 60¹3'26.9" W; 17 May 2012; J. Higuti leg.; with soft parts dissected in glycerine in sealed slides, valves stored dry in micropalaeontological slides after use for SEM; sample AMA 79; MZUSP 41862 • 3 우; Amazon River floodplain, Castanho Lake; 324'4.6" S, $60^{\circ} 13^{\prime 26.9 "}$ W; 17 May 2012; J. Higuti leg.; carapaces stored dry in micropalaeontological slides after use for SEM; sample AMA 79; MZUSP 41863 to MZUSP 41865.
\end{abstract}

\section{Other material examined}

BRAZIL • 2 우; Amazon River floodplain, Fuxico Lake; 3²5'21.5” S, 60²9'13" W; 16 May 2012; J. Higuti leg.; UEM-AMA 69; JH729, JH730 • 3 우; Amazon River floodplain, Jamauacá Lake; $3^{\circ} 22^{\prime} 33.1^{\prime \prime}$ S, 60¹7'55.1" W; 17 May 2012; J. Higuti leg.; UEM-AMA 73; JH731 to JH733.

\section{Measurements of illustrated specimens}

See Table 2.

\section{Description}

Remark: most of the material was slightly to considerably decalcified, so that dissections and SEM illustrations were difficult. The holotype male has two intact valves, but these were not used for SEM, because of the risk of damaging them. Other specimens were used for illustration, but no intact RV was available.

\section{Male}

LVi (Fig. 13A-C - slightly distorted owing to decalcification) with well-developed anterior calcified inner lamella, posterior calcified inner lamella narrow; an inner list running along and parallel to anterior, 
ventral and posterior valve margin, inwardly displaced anteriorly and posteriorly; anterior inner list running almost to the dorsal margin, posterior inner list running to the dorsal margin.

RVi (not illustrated) with well-developed anterior calcified inner lamella, posterior calcified inner lamella narrow; short anteroventral trace of an inner list and posteroventrally with an elevated inwardly displaced inner list and a submarginal selvage, both running parallel to the valve margin.

Greatest height in both valves situated in the middle of the smoothly curved dorsal margin. CpRl (Fig. 13E) elongated; dorsal margin smoothly arched; with the greatest height in the middle; external valve surface densely set with rimmed pores in shallow pits (Fig. 13D). CpD (Fig. 13F, H) and CpV (Fig. 13G) sub-ovate; with greatest width situated behind the middle; anterior margin pointed, posterior margin rounded; LV overlapping RV along the anterior, ventral and posterior margins, with a broad flap in the middle.

A1 (not illustrated) with seven segments. First segment large, ventrally with two long apical hirsute setae; dorsally with one short subapical hirsute seta, and with small Wouter's organ. Second segment subquadrate, with one short dorsal seta and a small ventral Rome organ. Third segment with two apical setae (the shorter ventral seta almost reaching the tip of the fourth segment; the longer dorsal seta reaching the edge of the fifth segment). Fourth segment with three apical setae, two long dorsal ones, and one ventral seta, the latter slightly shorter than the length of the fifth segment. Fifth segment with three apical setae, two long dorsal setae and one short ventral seta, the latter reaching half the length of the sixth segment. Sixth segment with four long apical setae. Terminal segment with two long setae, one shorter, but still elongated, aesthetasc Ya and one shorter seta, the latter almost the same length of the aesthetasc Ya.

A2 (Fig. 14A-B) with protopodite, exopodite and three-segmented endopodite. Protopodite ventrally with three setae: two unequal but short setae, one long apical seta reaching beyond the tip of the terminal segment. Exopodite reduced to a small plate with one long seta (reaching beyond the tip of the terminal segment) and two sub-equal short setae. First endopodal segment ventrally with aestethasc Y (more than $1 / 3$ of the length of this segment), one long hirsute ventral seta (reaching beyond the tip of the terminal segment), and five hirsute natatory setae, reaching beyond the tip of the end claws, and one short accompanying seta, about $1 / 2$ of the length of the second endopodal segment. Second endopodal segment with two unequal but long dorsal setae, one short hirsute ventral seta $t$; apically with three claws (G1, G2, z1) and three setae (G3, z2, z3). Terminal segment (Fig. 14B) with two claws, one long $(\mathrm{GM})$ and one short $(\mathrm{Gm})$ and one aesthetasc $\mathrm{y} 3$ with accompanying seta (slightly longer than the aesthetasc y3). Seta g absent.

Rake-like organ (not illustrated) stout, solid, T-shaped, with seven apical teeth.

Md-palp (not illustrated) with four segments. First segment with two long plumose setae $\left(\mathrm{S}_{1}\right.$ and $\left.\mathrm{S}_{2}\right)$, one long smooth seta and one short smooth seta $\alpha$. Second segment with three dorsal setae (two long and one shorter, ca $2 / 3$ the length of the two longer ones); ventrally with one hirsute seta $\beta$ and four long setae (three equally long, and one slightly shorter). Third segment with three groups of setae; dorsally one group of three unequal but long setae; laterally with one hirsute and stout apical seta $\gamma$ and three smooth setae; ventrally with three unequal shorter setae. Terminal segment with three claws and three setae.

Md-coxa (not illustrated) elongated, dorsally with a short seta, and with strong and apical teeth, interspaced with some setae.

Mx1 (not illustrated) consisting of three masticatory lobes (endites), a two-segmented palp and a large branchial plate (not illustrated). Branchial plate elongated, with ca 16 respiratory rays, some quite short, 

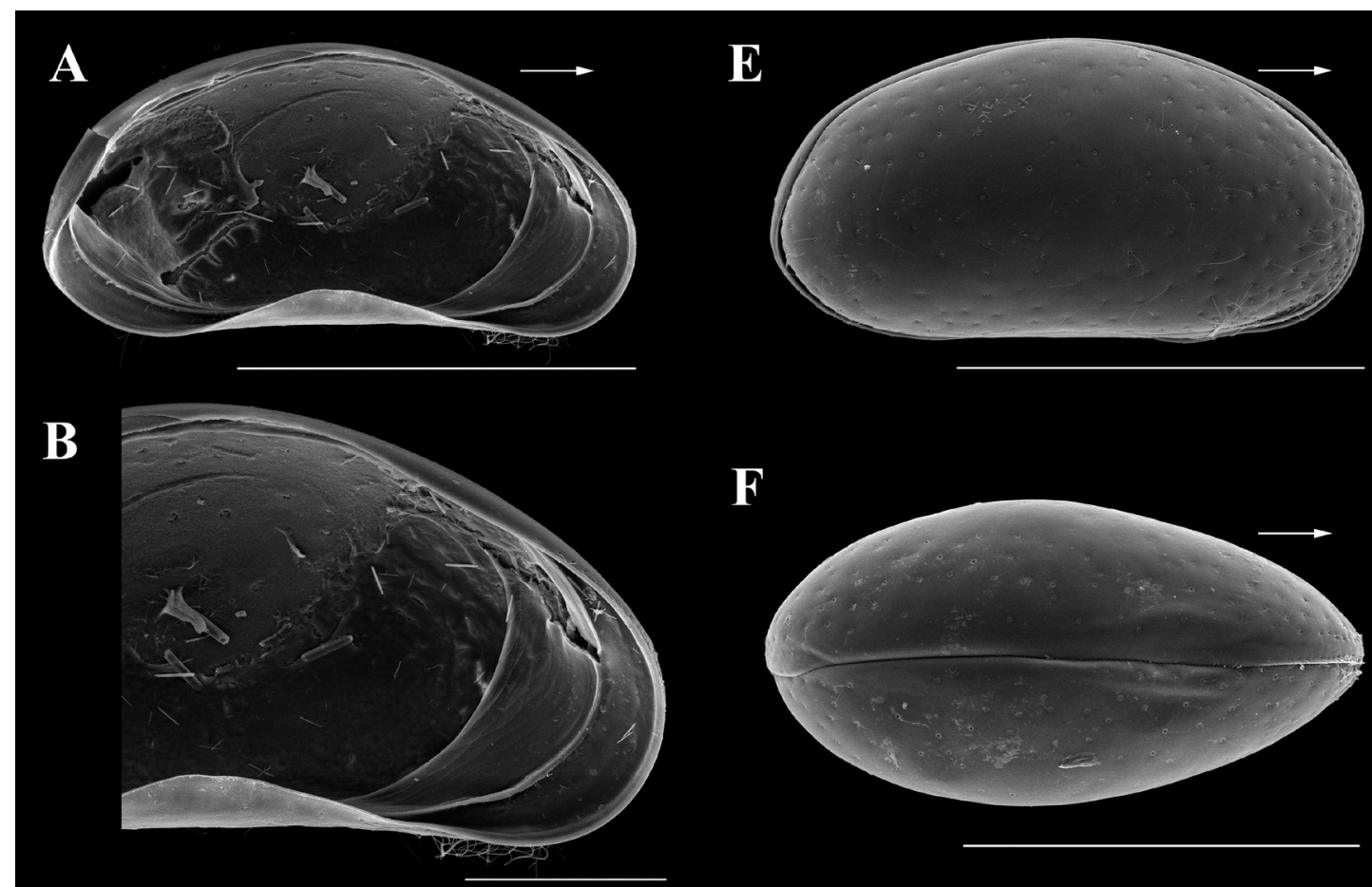

$\mathbf{F}$
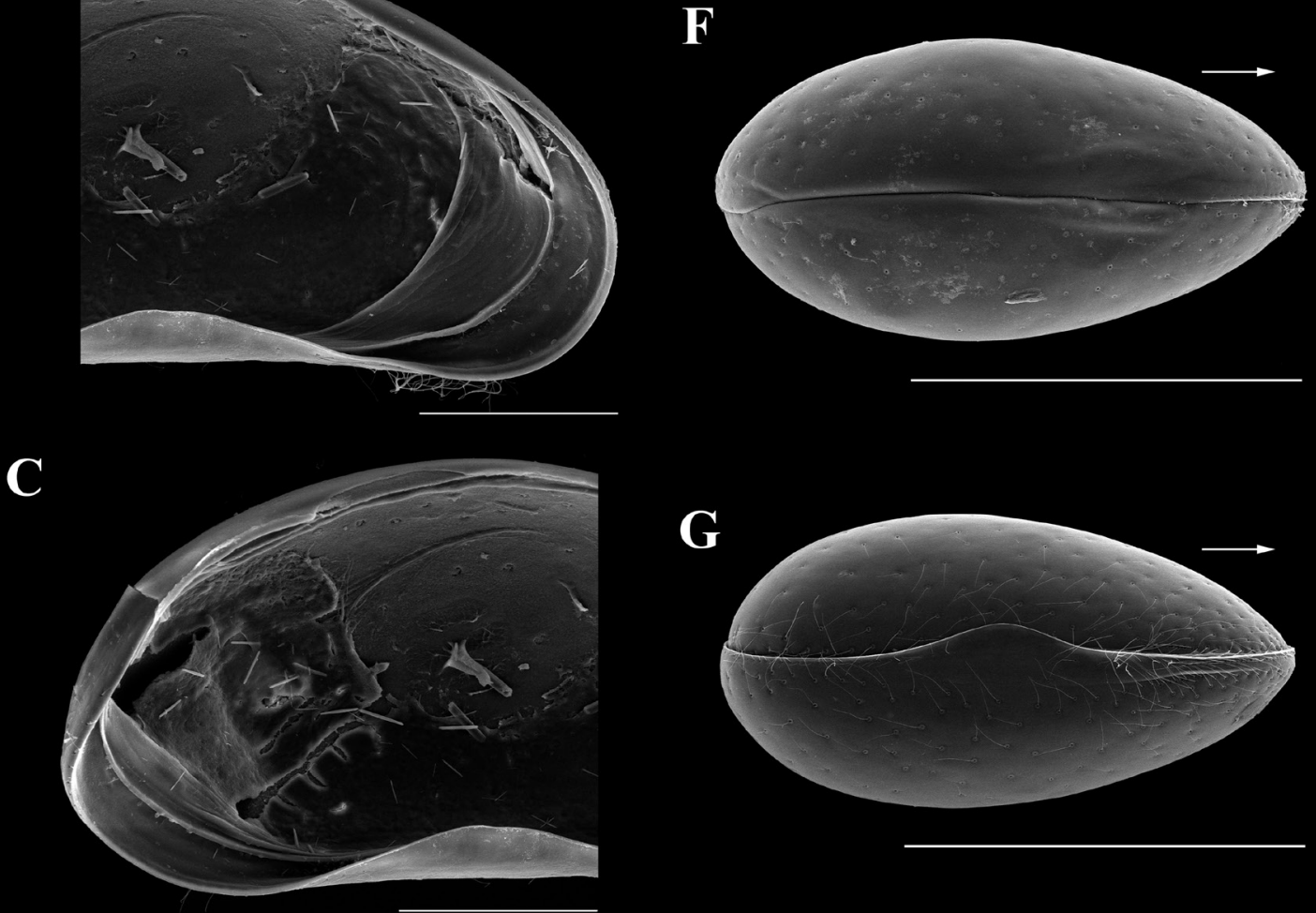

D

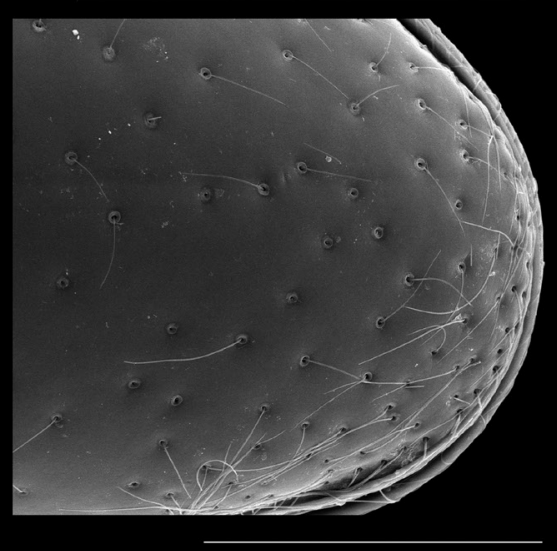

$\mathbf{H}$

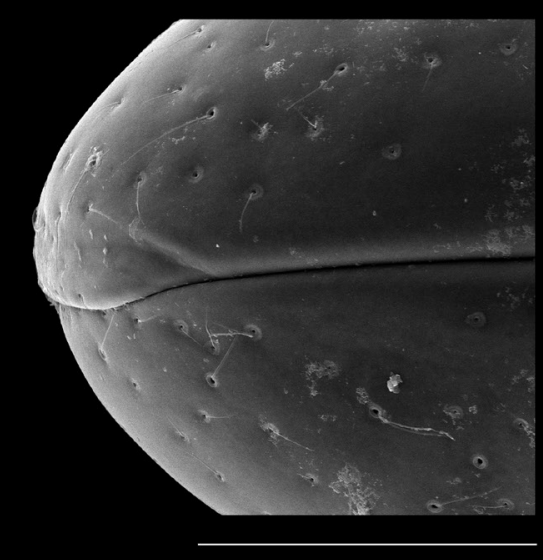

Fig. 13. Brasilodopsis amazonica gen. et sp. nov. from Amazon River floodplain, ô. A. LVi (MZUSP 41856). B. LVi, detail of anterior part (MZUSP 41856). C. LVi, detail of posterior part (MZUSP 41856). D. CpRl, detail of Cp surface (MZUSP 41857). E. CpRl (MZUSP 41857). F. CpD (MZUSP 41858). G. CpV (MZUSP 41859). H. CpD, detail of Cp surface (MZUSP 41858). Scale bars: $\mathrm{A}, \mathrm{E}-\mathrm{G}=300 \mu \mathrm{m} ; \mathrm{B}-\mathrm{D}, \mathrm{H}=100 \mu \mathrm{m}$. 

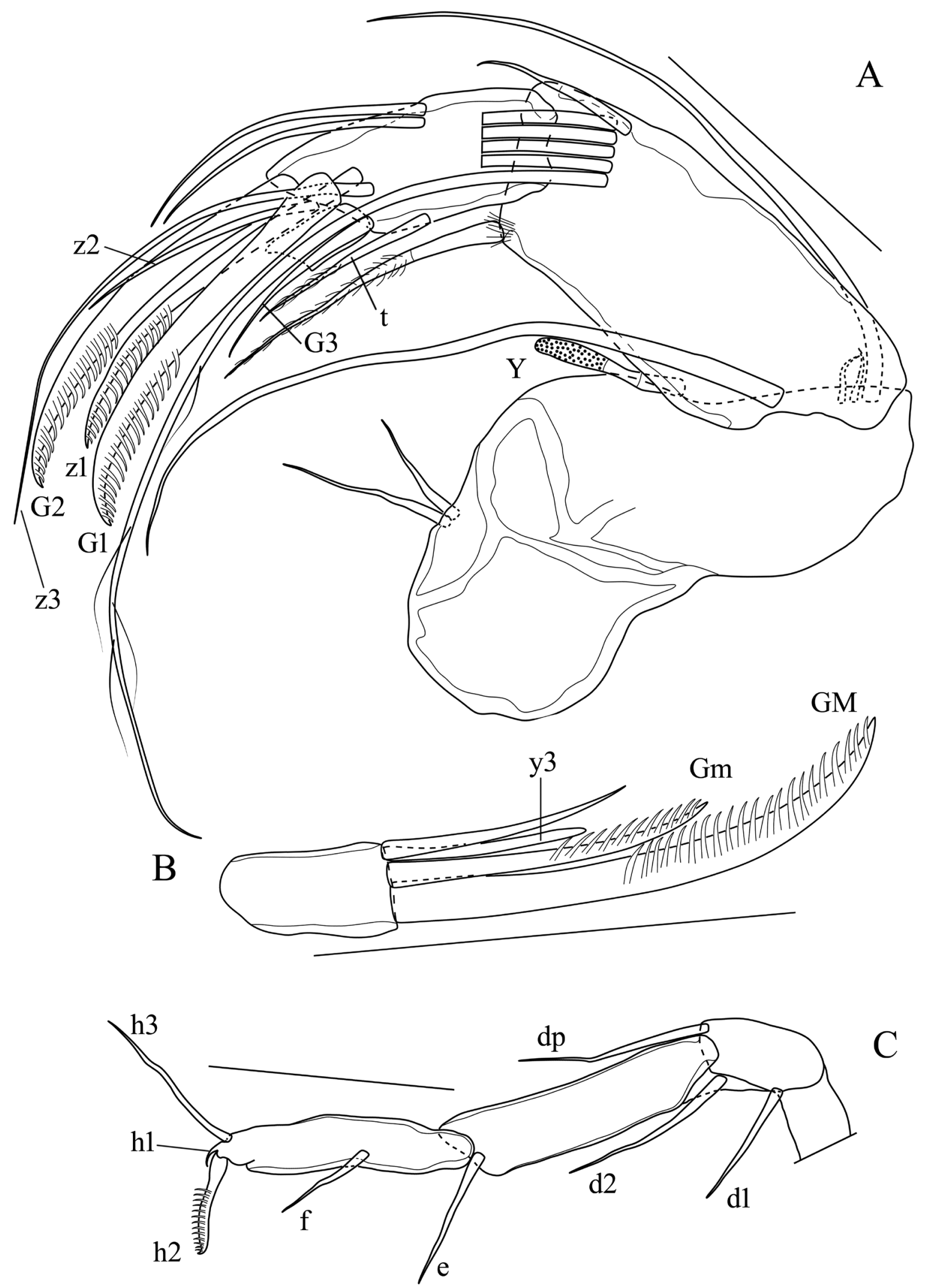

Fig. 14. Brasilodopsis amazonica gen. et sp. nov. from Amazon River floodplain, $\hat{o}^{\lambda}$. A. A2, without the terminal segment (MZUSP 41854). B. A2, terminal segment (MZUSP 41854). C. T3 (MZUSP 41854). Abbreviations: see text and Material and methods. Scale bars: $50 \mu \mathrm{m}$. 
others longer. First segment of palp with five setae (apically with four unequal but long setae and one short subapical seta, about $1 / 4$ of the longest one). Terminal segment of palp ca twice as long as basal width, apically with two claw-like setae and two setae. Third endite apically with two serrated claws and several setae. First endite at its base with two unequal setae and apically with ca five unequal, sideways directed bristles.

T1 protopodite (Fig. 15A-C) apically with a group of eight hirsute setae, and two short setae a inserted in the middle, seta d absent. Endopodites (Fig. 15B-C) asymmetrical prehensile palps: Rpp (Fig. 15B) with first segment rather stout, with two small subapical spines, second segment with triangular lobe, with uneven dorsal and slightly curved distal margin. Lpp (Fig. 15C) with first segment elongated, with two sub-apical spines, second segment sickle-shaped, with swollen basis and blunt distal part.

T2 (not illustrated) with protopodite, a 'knee'-segment and four endopodite segments. Protopodal segment without seta d1. 'Knee'-segment with one short subapical seta d2. First endopodal segment with one apical hirsute seta e, reaching the middle of the second endopodal segment. Second endopodal segment with one apical hirsute seta f, reaching beyond the tip of the fifth segment. Third endopodal segment with one subapical hirsute seta g, approximately half of the length of the seta $\mathrm{f}$. Terminal segment with one apical serrated claw h2, one short hirsute subapical seta h1 and a very short seta h3.

T3 (Fig. 14C) with three segments. First segment with two unequal long setae $\mathrm{d} 2$ and dp and one shorter seta d1. Second segment with one subapical seta e, reaching beyond the middle of the third segment. Third segment medially with one seta $f$, about $1 / 2$ the length of the third segment. Distal part of third segment with a pincer structure, one small spine-like structure (h1), one long subapical seta h3, about $1.5 \times$ the length of the broad seta $\mathrm{h} 2$, the latter set with spine-like setulae.

Zenker's organ (Fig. 15D) about 4 times as long as wide, with approximately 10 series of sw.

Hemipenis (Fig. 15E-M) with ventral lobe of ms rounded, ventral lobe of ls bird head-shaped with bluntly pointed distal beak. Post-labyrinthal spermiduct with two loops: one large, one much smaller (Fig. 15E).

Remark: the outline of the hemipenis can show some variability within one specimen and between specimens. Therefore, the hemipenis outlines of four males have been illustrated in Fig. 15F-M.

\section{Female}

Remark: also here, some specimens were decalcified and this caused some distortion of the single valves in the SEM illustrations.

LVi (Fig. 16A, C-D), RVi (Fig. 16B, E-F), CpRl (Fig. 16G), CpD (Fig. 16H) and CpV (Fig. 16I) as in the male.

A1, Rake-like organ, Md-coxa, Mx1 and T2 (not illustrated) as in the male.

A2 (Fig. 17A-B) with protodopodite, exopodite and three-segmented endopodite. Protopodite ventrally with three setae: two unequal but short setae, one long apical seta reaching beyond the tip of the terminal segment. Exopodite reduced to a small plate with one long seta (reaching beyond the tip of the terminal segment) and two sub-equal short setae. First endopodal segment ventrally with aestethasc $Y$ (ca $1 / 4$ of the length of this segment), one long hirsute ventral seta (reaching beyond the tip of the terminal segment), and five hirsute natatory setae, reaching beyond the tip of the end claws, and one short accompanying seta, about $1 / 2$ of the length of the second endopodal segment. Second endopodal segment with two unequal, but long dorsal setae, four ventral setae $t$ (two unequal but long, one ca e half of the length of the longest setae, and one short, approximately $1 / 4$ of longest setae); apically with three claws (G1, G2, G3) and three setae (z1, z2, z3). Terminal segment (Fig. 17B) with two claws, one long (GM) one short $(\mathrm{Gm})$ and one aesthetasc $\mathrm{y} 3$ with accompanying seta, slightly longer than y3. Seta g absent. 

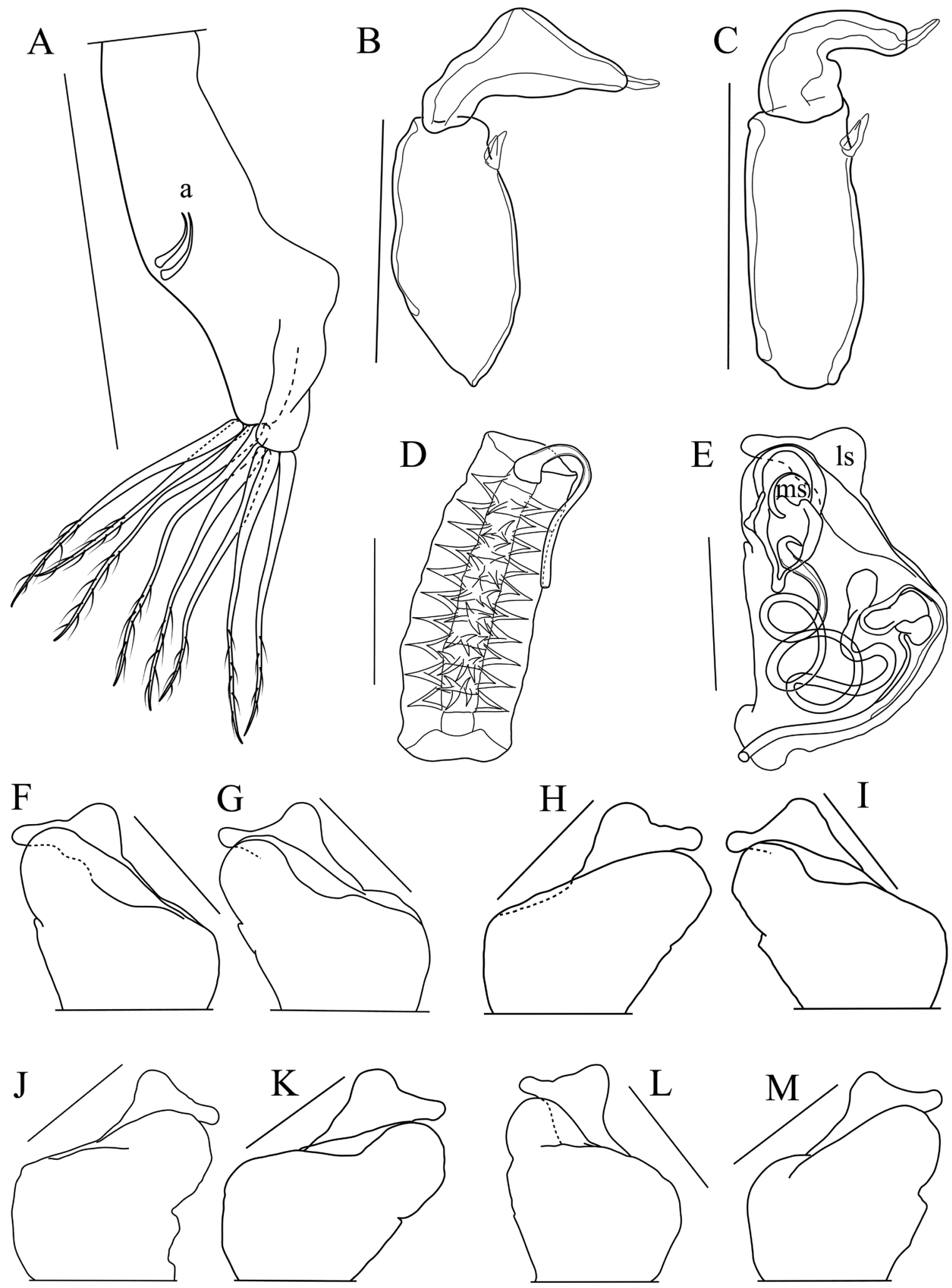

Fig. 15. Brasilodopsis amazonica gen. et sp. nov. from Amazon River floodplain, §. A. T1 (MZUSP 41852). B. Rpp (MZUSP 41852). C. Lpp (MZUSP 41852). D. Zenker's organ (MZUSP 41852). E-G. Hemipenis (MZUSP 41852). H-I. Hemipenis (MZUSP 41856). J-K. Hemipenis (MZUSP 41854). L-M. Hemipenis (MZUSP 41855). Abbreviations: see text and Material and methods. Scale bars: $50 \mu \mathrm{m}$. 


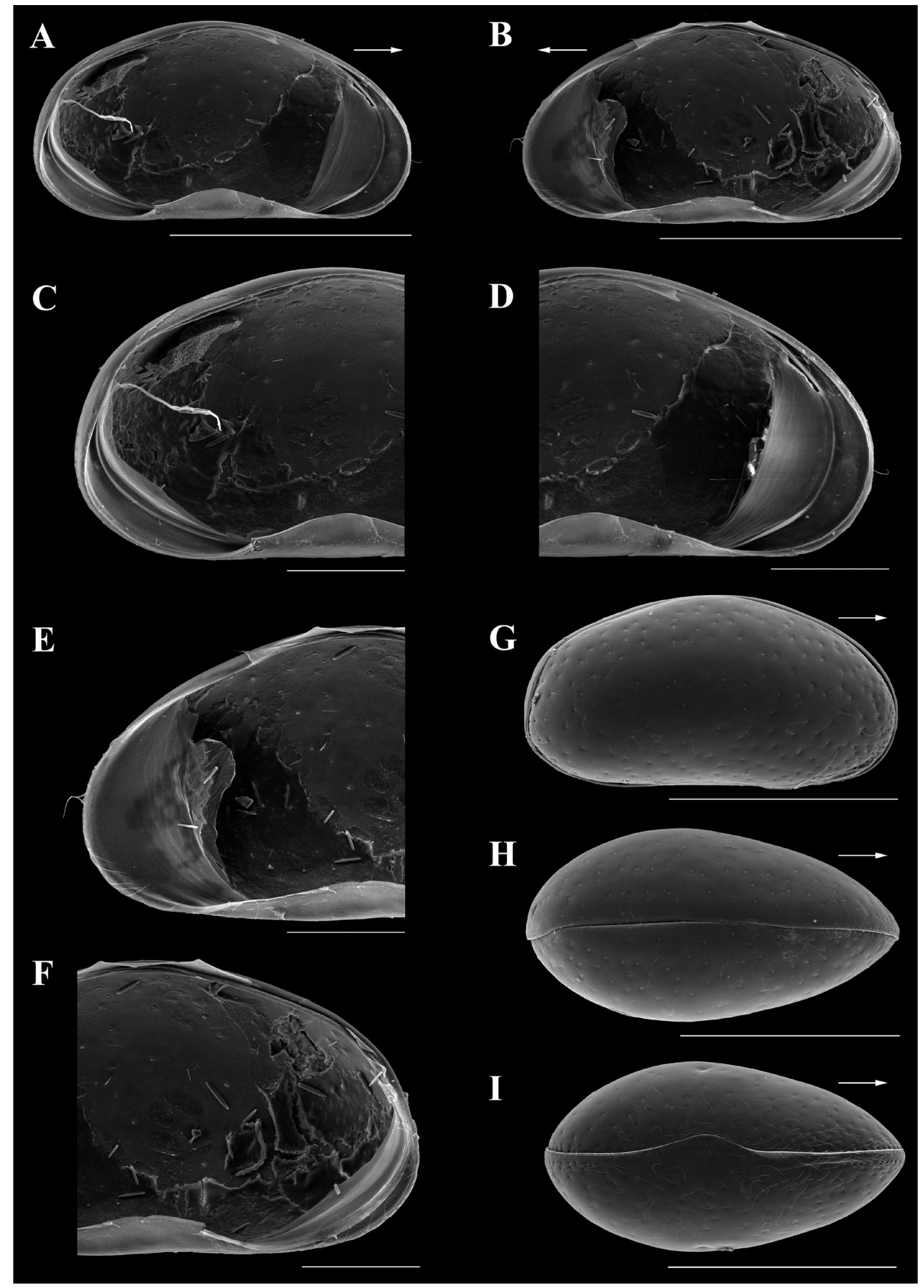

Fig. 16. Brasilodopsis amazonica gen. et sp. nov. from Amazon River floodplain, ${ }_{+}$. A. LVi (MZUSP 41862). B. RVi (MZUSP 41862). C. LVi, detail of posterior part (MZUSP 41862). D. LVi, detail of anterior part (MZUSP 41862). E. RVi, detail of anterior part (MZUSP 41862). F. RVi, detail of posterior part (MZUSP 41862). G. CpRl (MZUSP 41863). H. CpD (MZUSP 41864). I. CpV (MZUSP 41865). Scale bars: A-B, G-I $=300 \mu \mathrm{m} ; \mathrm{C}-\mathrm{F}=100 \mu \mathrm{m}$. 


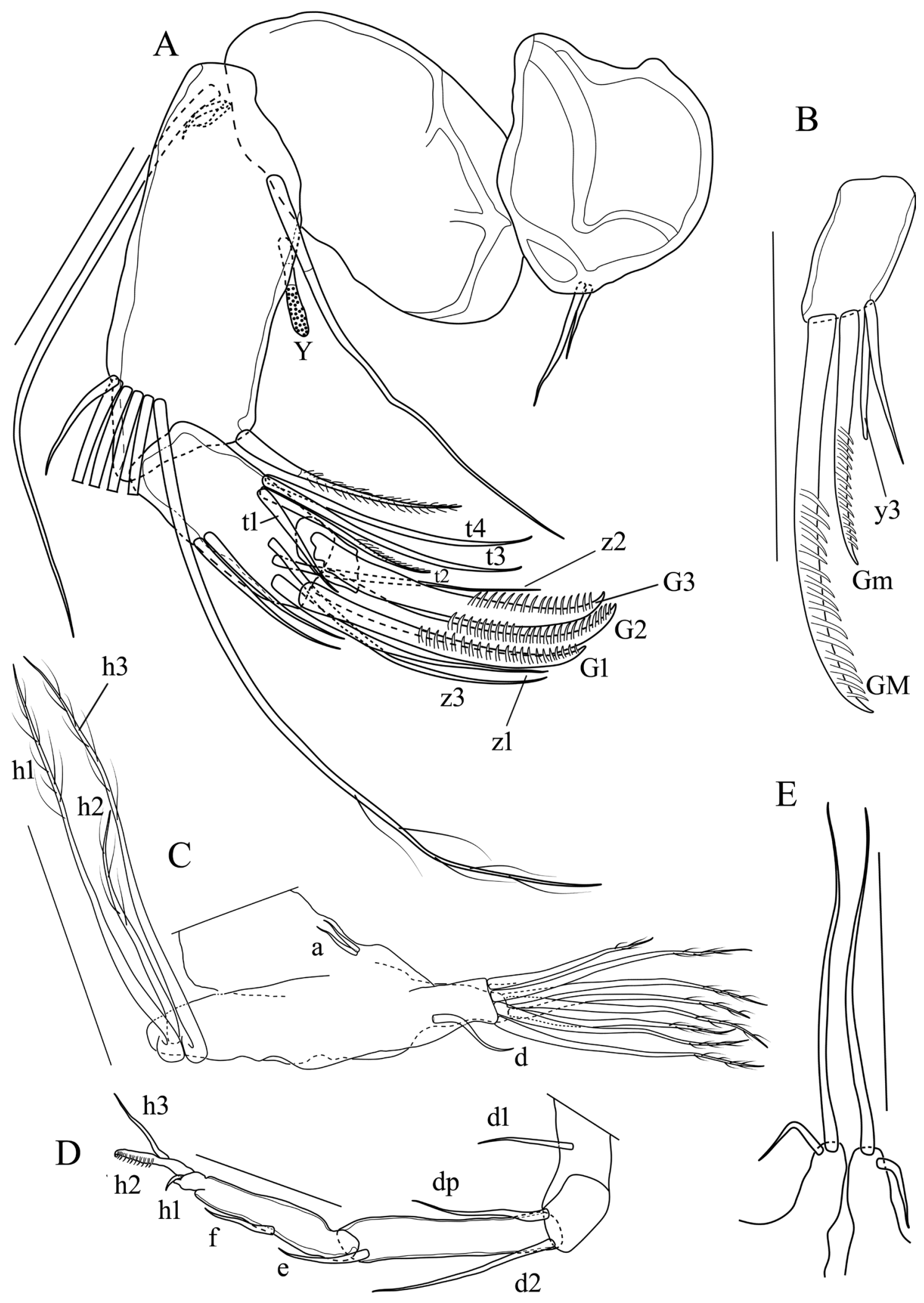

Fig. 17. Brasilodopsis amazonica gen. et sp. nov. Amazon River floodplain, 9 . A. A2, without the terminal segment (MZUSP 41853). B. A2, terminal segment (MZUSP 41853). C. T1 (MZUSP 41861). D. T3 (MZUSP 41862). E. CR (MZUSP 41861). Abbreviations: see text and Material and methods. Scale bars: $50 \mu \mathrm{m}$. 
T1 (Fig. 17C) protopodite with a group of eight hirsute setae; two short seta a, one long seta d. Endopodite consisting of three long plumose setae.

T3 (Fig. 17D) with three segments. First segment with two unequal long setae $\mathrm{d} 2$ and dp and one shorter seta d1. Second segment with one subapical seta e, almost smaller than the half of the third segment. Third segment medially with one seta $f$, about $1 / 3$ the length of the third segment. Distal part of third segment with a pincer structure, one small spine-like structure h1, one long subapical seta h3, slightly longer than the broad seta $\mathrm{h} 2$, the latter set with spine-like setulae.

CR (Fig. 17E) with elongated base (2-3 times as long as wide), one subapical short seta and one long apical seta (ca 3-5 times the length of the base).

\section{Differential diagnosis}

Cp sub-ovate, slightly more elongated and with smoothly curved dorsal margin (with blunt dorsal corner in Brasilodopsis baiabonita gen. et sp. nov.). Posterior inner list in LV more slender than in B. baiabonita gen. et sp. nov. (see Table 3). External valve surface densely set with rimmed pores in shallow pits (smooth, with sparse setae and pores in B. baiabonita gen. et sp. nov.). Hemipenis outline similar in both species, but distal segments of prehensile palps with subtle differences.

\section{Ecology and distribution}

Brasilodopsis amazonica gen. et sp. nov. was recorded only from the Amazon River floodplain, in association with several aquatic macrophytes. The range of the water temperature was between 31.5 and $32.9^{\circ} \mathrm{C}$. The $\mathrm{pH}$ range remained slightly acid (6.4 and $6.7-$ hence possibly the decalcified valves). The ranges of electrical conductivity and dissolved oxygen were from 41.5 to $67.1 \mu \mathrm{S}_{\mathrm{cm}} \mathrm{cm}^{-1}$, and from 0.4 to $3 \mathrm{mg} . \mathrm{L}^{-1}$, respectively (see Table 4).

Tribe Paranadopsini trib. nov. urn:Isid:zoobank.org:act:E3A91D7A-CDF0-47FF-92A7-ADBBE6431FFC

\section{Type genus}

Paranadopsis gen. nov. (here described).

\section{Diagnosis}

Cp elongated and bean-shaped, with curved ventral margin. LV largely overlapping RV, especially along the anterior side. LV with weak anterior and ventral inner list, posterior inner list fully absent. RV without anterior inner list, posteriorly with weakly inwardly displaced selvage. Several limbs with segments reduced in length and/or in chaetotaxy: A1 with four distal segments highly reduced in both length and chaetotaxy; A2 with one short natatory seta (or its accompanying seta) only and reduced length of two distal segments. Idem for Md-palp, Mx1, T1 and T2 (where both setae d1 and d2 are missing). Male unknown.

\section{Remarks}

Because of the structural reduction in both valves (inner lists mostly absent) and the limbs (especially in the A1, but also in most other limbs) it is clear that this new genus and its species do not belong in the tribe Cypridopsini and require a new tribe, which might in time even be elevated to the rank of subfamily. 


\section{Paranadopsis gen. nov. \\ urn:1sid:zoobank.org:act:D8BF39A1-2843-4C13-9230-1AA6A3F71EE5}

\section{Type species}

Paranadopsis reducta gen. et sp. nov. (here designated).

\section{Diagnosis}

As for the new tribe.

\section{Etymology}

The new genus is named after the state and the river from which it is here described, namely Paraná, and 'dopsis', referring to the stem of Cypridopsis.

\section{Differential diagnosis}

Paranadopsis gen. nov. can be distinguished from all other cypridopsine genera by the combination of the valve and limb morphology, including the strong reduction of size and chaetotaxy of segments in various limbs, especially in the A1 (see above, diagnosis of new tribe) (see Table 3).

\section{Paranadopsis reducta gen. et sp. nov. urn:lsid:zoobank.org:act:8F976A25-DBBF-4F8C-AD42-EA8BCF527C7B} Figs 18-21

'Cypridopsis' nov. gen. nov. sp. - Higuti et al. 2007: 1935, table 2.

"Cypridopsis" n. gen. 2 n. sp. - Matsuda et al. 2015a: 326-327, tables 1-2. - Conceição et al. 2017: 329, table 2; 2018: 184, table 3. - Higuti et al. 2017b: 327, table 2.

Cypridopsis n.gen. 2 n.sp. - Matsuda et al. 2015b: 118, 123, table 1, fig. 5.

“Cypridopsis" sp. 2 n.gen. n.sp. - Campos et al. 2018: 6, table 2; 2019: 375, table 1.

Cypridopsis n.gen. 2 n.sp.1 - Higuti et al. 2020: 2, table S1.

\section{Diagnosis}

As for the tribe and genus. As the tribe is monogeneric and the genus is monospecific, it is difficult to allocate the different characters and character states to the different taxonomic levels. It is expected that other species in this genus and other genera in this tribe will have basically the same body plan, with slight modifications in shape, size and chaetotaxy of segments in various limbs.

\section{Etymology}

The new species is named after the fact that much of the size, shape and chaetotaxy of the segments in the limbs is reduced, especially in the A1.

\section{Type material examined}

\section{Holotype}

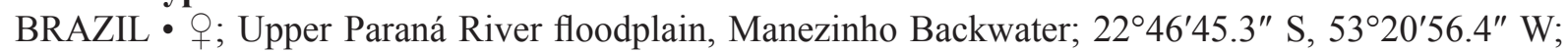
2 Mar. 2007; J. Higuti leg.; with soft parts dissected in glycerine in a sealed slide, valves stored dry in a micropalaeontological slide; sample EC1; MZUSP 41866.

\section{Paratypes}

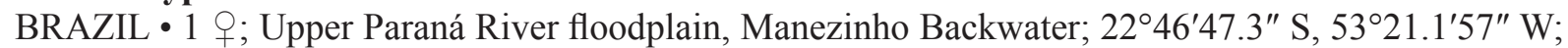
3 May 2010; J. Higuti leg.; with soft parts dissected in glycerine in a sealed slide; valves stored dry in a micropalaeontological slide; sample EC3; MZUSP 41867 • 1 क ; Upper Paraná River floodplain,

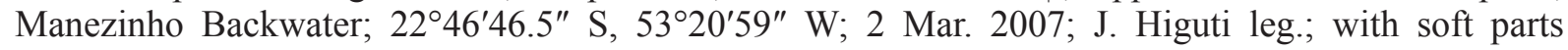
dissected in glycerine in a sealed slide, valves stored dry in a micropalaeontological slide; sample EC2; 
MZUSP 41868 - 1 q; Upper Paraná River floodplain Manezinho Backwater; 2246'47.3" S, $53^{\circ} 21.1^{\prime} 57^{\prime \prime}$ W; 6 Jul. 2011; J. Higuti leg.; with soft parts dissected in glycerine in a sealed slide, valves stored dry in a micropalaeontological slide; sample EC3; MZUSP 41869 • 1 \%; Upper Paraná River

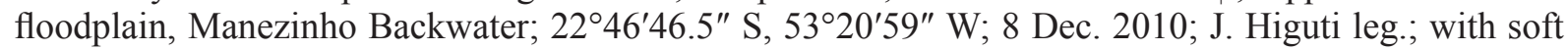
parts dissected in glycerine in a sealed slide, valves stored dry in a micropalaeontological slide; sample EC2; MZUSP 41870 • 1 क; Upper Paraná River floodplain, Manezinho Backwater; 22 46'47.3" S, 5321.1'57" W; 8 Dec. 2010; J. Higuti leg.; with soft parts dissected in glycerine in a sealed slide, valves stored dry in a micropalaeontological slide; sample EC3; MZUSP 41871 • 1 क; Upper Paraná

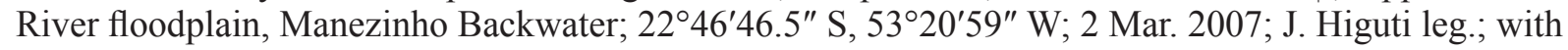
valves stored dry in a micropalaeontological slide after use for SEM; sample EC2; MZUSP 41872 •

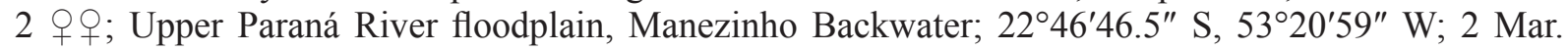
2007; J. Higuti leg.; carapaces stored dry in micropalaeontological slides after use for SEM; sample EC2; MZUSP 41873, MZUSP 41874 • 1 +; Upper Paraná River floodplain, Manezinho Backwater; $22^{\circ} 46^{\prime} 46.5^{\prime \prime} \mathrm{S}, 53^{\circ} 20^{\prime} 59^{\prime \prime} \mathrm{W} ; 3$ May 2010; J. Higuti leg.; carapace lost after use for SEM; sample EC2; $\mathrm{JH} 490$.

\section{Measurements of illustrated specimens}

See Table 2.

\section{Description}

\section{Female}

LVi (Fig. 18A, C-D) with broad anterior calcified inner lamella and narrower posterior calcified inner lamella; weak inner list present anteriorly and ventrally, absent posteriorly. RVi (Fig. 18B, E-F) with broad anterior calcified inner lamella and narrower posterior calcified inner lamella; inner list fully absent, posteriorly with an inwardly displaced selvage. Both valves elongated and bean-shaped, with curved ventral margin, evenly rounded dorsal margin and with anterior margin more broadly rounded than posterior one. CpRl (Fig. 18G) elongated; with the greatest height situated in front of the middle; LV overlapping RV anteriorly (widely so) and posteriorly. External valve surface smooth and set with isolated setae. CpD (Fig. 18H) sub-ovate; with greatest width in the middle, and with LV widely overlapping RV anteriorly and less so posteriorly. CpV (Fig. 18I) also sub-ovate; with the greatest width in the middle; LV overlapping RV especially anteriorly, but also ventrally and posteriorly and with a gap between the two valves in the anterior third of the length, immediately followed by a central flap of the LV extending beyond the RV.

A1 (Fig. 19A) with seven segments. First segment with two long subapical ventral setae; Wouter's organ not seen. Second segment with one long dorso-lateral seta; Rome organ not seen. Third segment with one ventro-lateral and one dorso-apical setae, the latter slightly shorter than the former one. Fourth to seventh segment greatly reduced in length and chaetotaxy. Fourth segment without setae. Fifth segment with one dorso-apical seta. Sixth segment with three long apical setae. Terminal (seventh) segment with two apical setae, one long and one half that length, and one aesthetasc Ya, about $2 / 3$ of the shorter seta.

A2 (Fig. 19B, D) with prodopodite, exopodite and three-segmented endopodite. First segment with one long subapical seta reaching well beyond the tip of the terminal segment. Exopodite reduced to a small plate (not illustrated), with only one long seta reaching the tip of the first endopodal segment; two short accompanying setae missing. First endopodal segment with a ventral aesthetasc $\mathrm{Y}$ (approximately half the length of the segment), one subapical long seta, about $2.5 \times$ the length of aesthetasc $\mathrm{Y}$ and hirsute in its distal one fifth, and medially with one short (natatory) seta, almost reaching the tip of the second endopodal segment. Second endopodal segment ventrally with three setae $t$ (one short seta, about twice the length of the terminal segment; one long ca twice the length of the shortest setae,

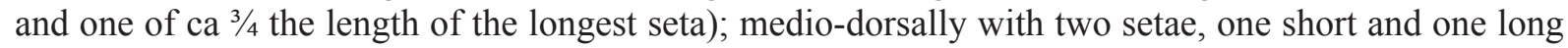
(ca twice the length of the short one); apically with three claws (G1, G2, G3) and three setae (z1, z2, z3). Terminal segment (Fig. 19D) with two claws, one long (GM), one short (Gm) and one aesthetasc y3 with one accompanying seta, the first one slightly shorter than the latter; seta $\mathrm{g}$ missing. 

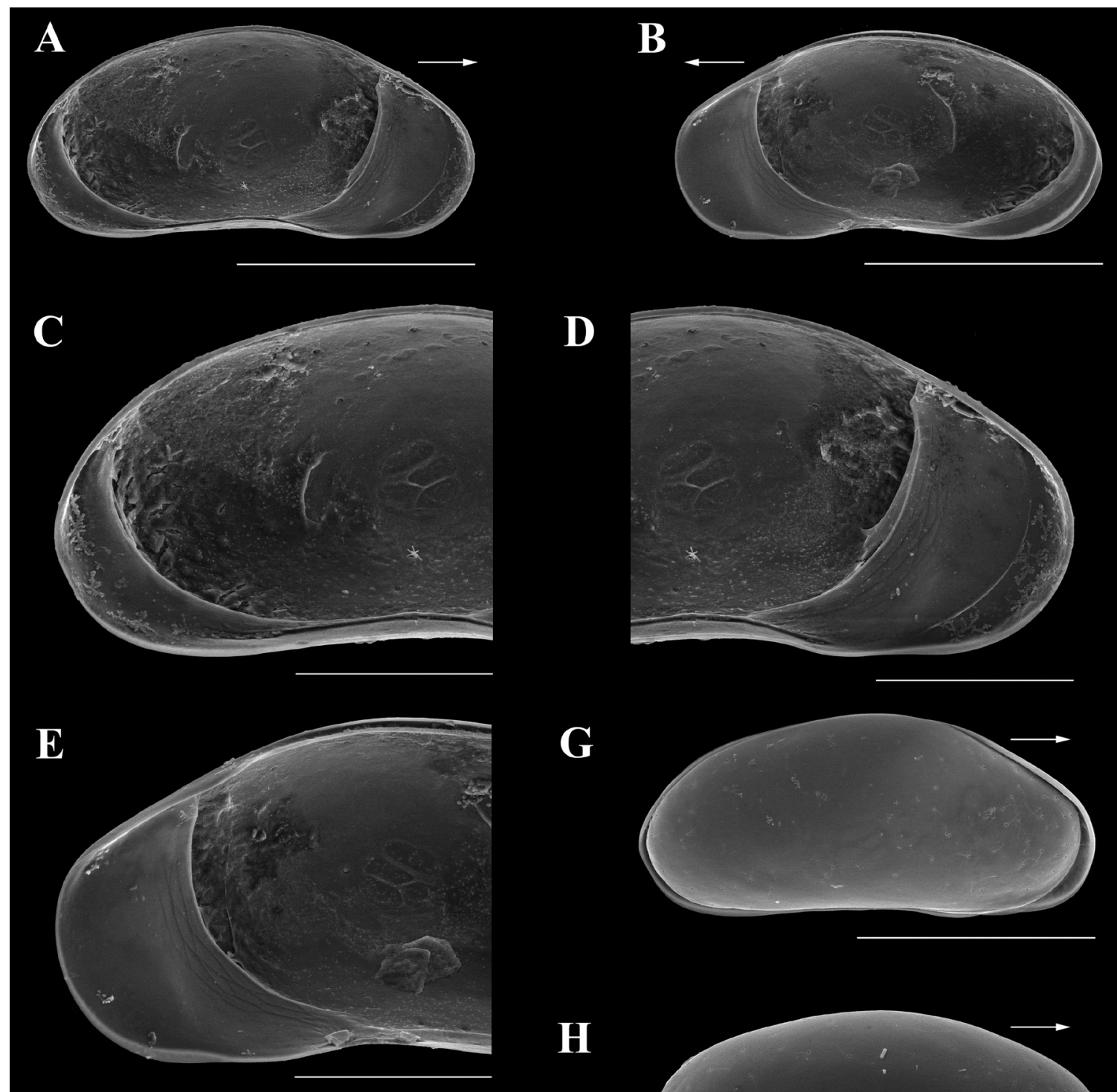

D
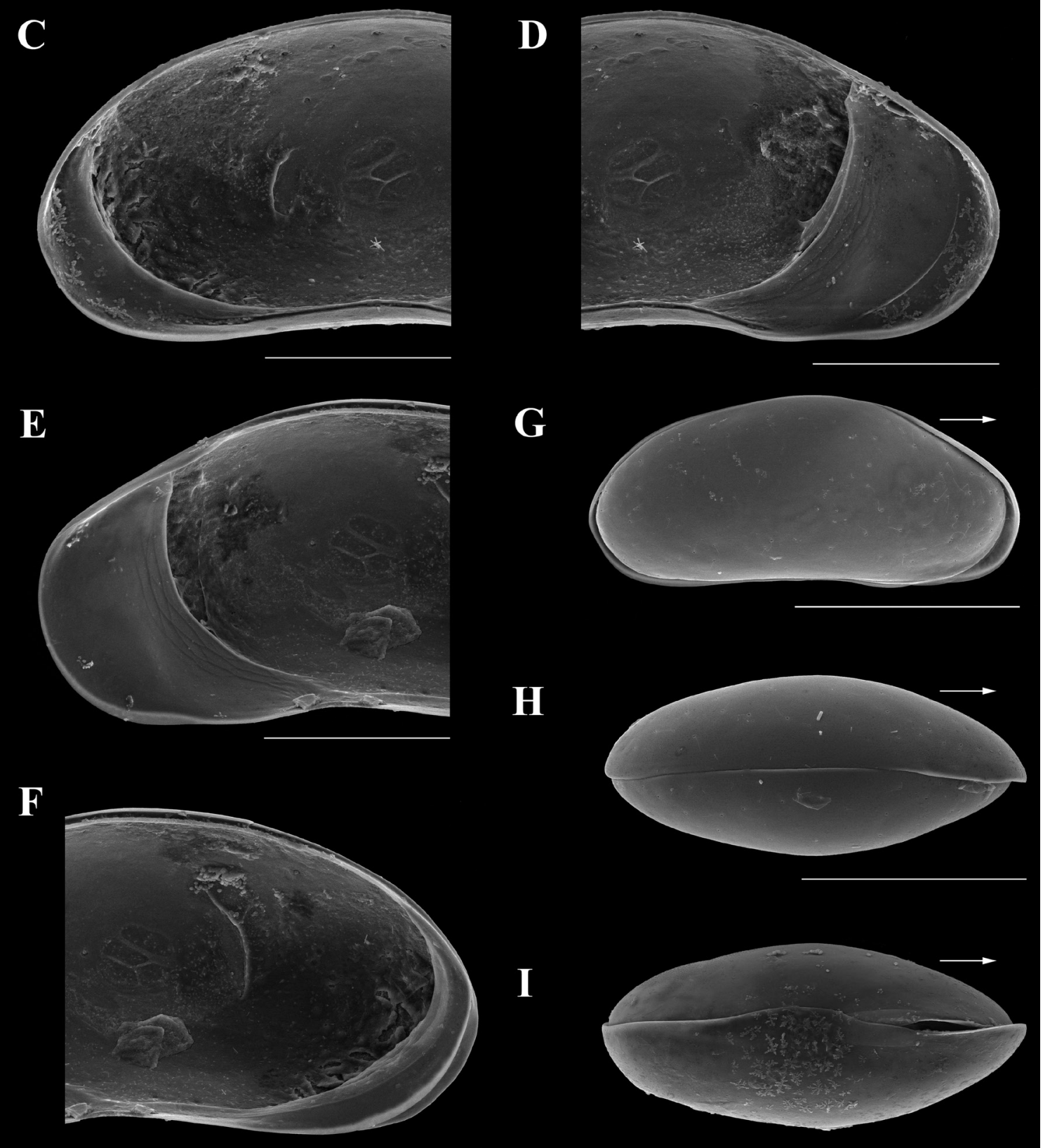

Fig. 18. Paranadopsis reducta gen. et sp. nov. from the Upper Paraná River floodplain, 9 . A. LVi (MZUSP 41872). B. RVi (MZUSP 41872). C. LVi, detail of posterior part (MZUSP 41872). D. LVi, detail of anterior part (MZUSP 41872). E. RVi, detail of anterior part (MZUSP 41872). F. RVi, detail of posterior part (MZUSP 41872). G. CpRl (MZUSP 41873). H. CpD (MZUSP 41874). I. CpV (JH490). Scale bars: A-B, G-I $=200 \mu \mathrm{m} ; \mathrm{C}-\mathrm{F}=100 \mu \mathrm{m}$. 


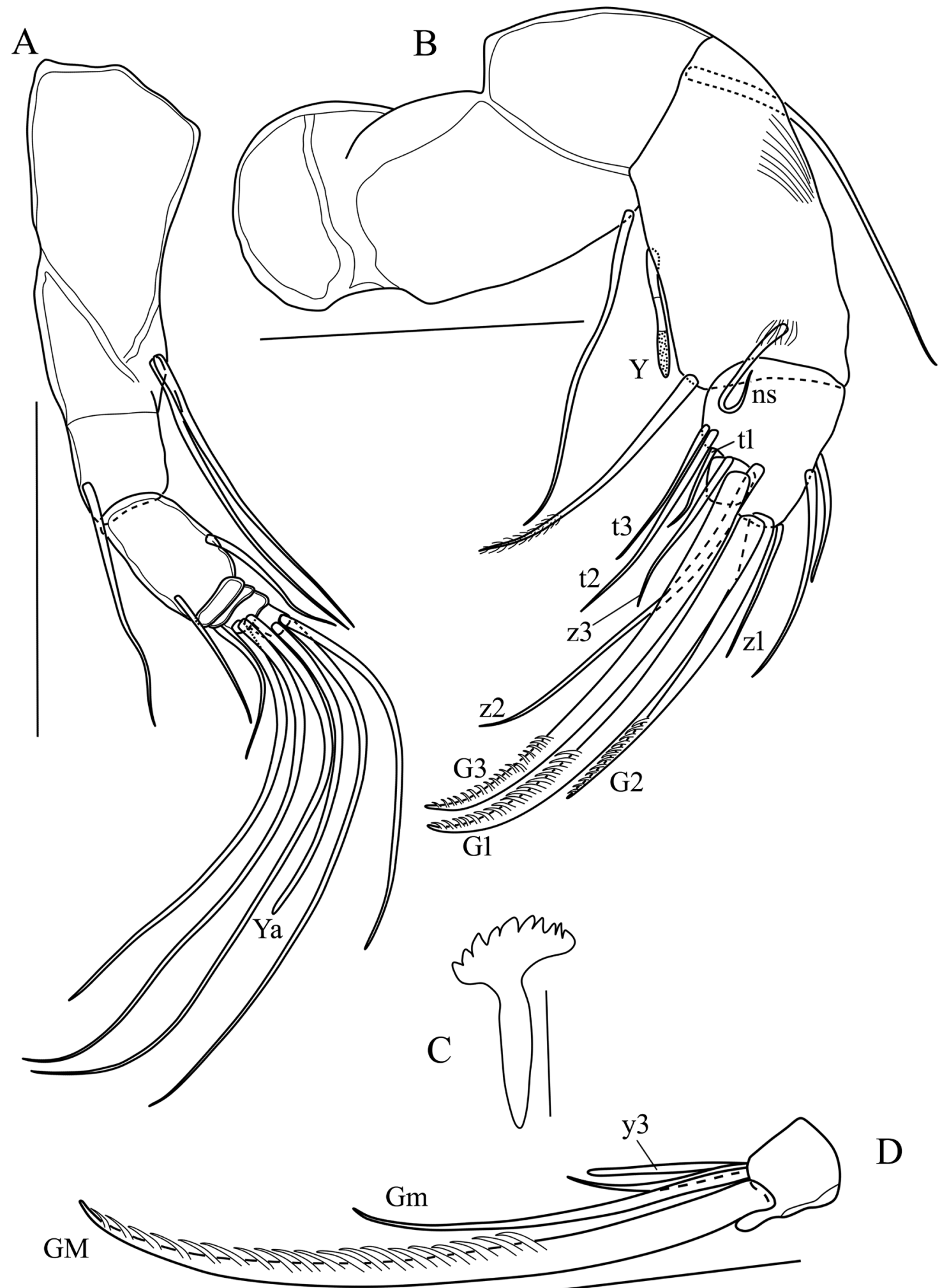

Fig. 19. Paranadopsis reducta gen. et sp. nov. from the Upper Paraná River floodplain, 9 . A. A1 (MZUSP 41866). B. A2, without the terminal segment (MZUSP 41868). C. Rake-like organ (MZUSP 41869). D. A2, terminal segment (MZUSP 41868). Abbreviations: see text and Material and methods. Scale bars: A-B, D $=50 \mu \mathrm{m} ; \mathrm{C}=10 \mu \mathrm{m}$. 
Rake-like organ (Fig. 19C) stout, solid, T-shaped, with ca ten apical teeth.

Md-palp (Fig. 20B) with four segments. First segment with two long plumose setae $\left(\mathrm{S}_{1}\right.$ and $\left.\mathrm{S}_{2}\right)$, one long smooth seta and one short smooth seta $\alpha$. Second segment with two unequal, but long dorsal setae; ventrally with one seta $\beta$, and one long seta (ca $2 \times$ the length of seta $\beta$ ). Third segment with three groups of setae; dorsally with one group of three long setae and one short (hirsute) seta; apically with a group of three setae, one of which being seta $\gamma$; ventro-apically with two unequal setae. Terminal segment with three claws and three setae.

Md-coxa (Fig. 20A) elongated, with strong apical teeth, interspaced with some setae.

Mx1 (Fig. 20C - chaetotaxy not completely illustrated) consisting of three masticatory lobes (endites), a two-segmented palp and a large branchial plate (the latter not illustrated). Branchial plate elongated, with ca 12 respiratory rays, some quite short, others long. First segment of palp subapically with two long setae. Terminal segment of palp with two claw-like setae and two short setae. Third endite apically with several setae, two with a distal tuft of setulae, and one basal, long seta. First endite apically with one basal seta and ca four sideways directed bristles.

T1 (Fig. 21A) protopodite with a group of six hirsute setae and two short setae $\mathrm{a}$; setae $\mathrm{b}$ and $\mathrm{d}$ absent. Endopodite consisting of two apical plumose setae (one long and one short about $1 / 2$ the length of the long one).

T2 (Fig. 21B) with one protopodite segment, one 'knee' segment and four endopodite segments. Protopodite and knee-segment with setae $\mathrm{d} 1$ and $\mathrm{d} 2$ absent. First endopodal segment with one subapical seta e, not reaching the tip of the second endopodal segment. Second endopodal segment with one apical seta f, reaching beyond the tip of the fifth segment. Third endopodal segment with one sub-apical seta $\mathrm{g}$. Terminal endopodal segment with one apically serrated claw h2; setae h1 and h3 absent.

T3 (Fig. 21C) with three segments. First segment with three long setae (d1, d2, dp). Second segment with one apical seta e, reaching the middle of the third segment. Third segment medially with one seta $\mathrm{f}$, about $1 / 3$ of the length of the third segment. Distal part of third segment fused with fourth segment into a pincer structure, with a claw h2, one short seta h1 and one long seta h3, about $2 \times$ the length of seta $h 2$.

CR absent.

\section{Male}

Unknown.

\section{Ecology and distribution}

Paranadopsis reducta gen. et sp. nov. was found associated with the root system of E. crassipes, located in some lakes of the Upper Paraná River floodplain. The temperature range of these lakes at the time of sampling was 28.3 to $32.6^{\circ} \mathrm{C}$, while the $\mathrm{pH}$ range was 5.8 to 7 . The electrical conductivity range was 14 to $61 \mu \mathrm{S} . \mathrm{cm}^{-1}$, and the dissolved oxygen range was 1.5 to $7.6 \mathrm{mg} . \mathrm{L}^{-1}$ (see Table 4 ).

The species can be considered as rare in the area.

\section{Discussion}

\section{Taxonomic position of the Cypridopsinae}

Kaufmann (1900) described the subfamily Cypridopsinae in the family Cyprididae, based mainly on the presence of a flagellum-like CR. Hartmann \& Puri (1974) escalated this taxon to the family Cypridopsidae, in which they included, following Hartmann (1963), both the original Cypridopsinae, with CR reduced to a flagellum, and the Cyprettinae Hartmann, 1963, in which the CR shows various 

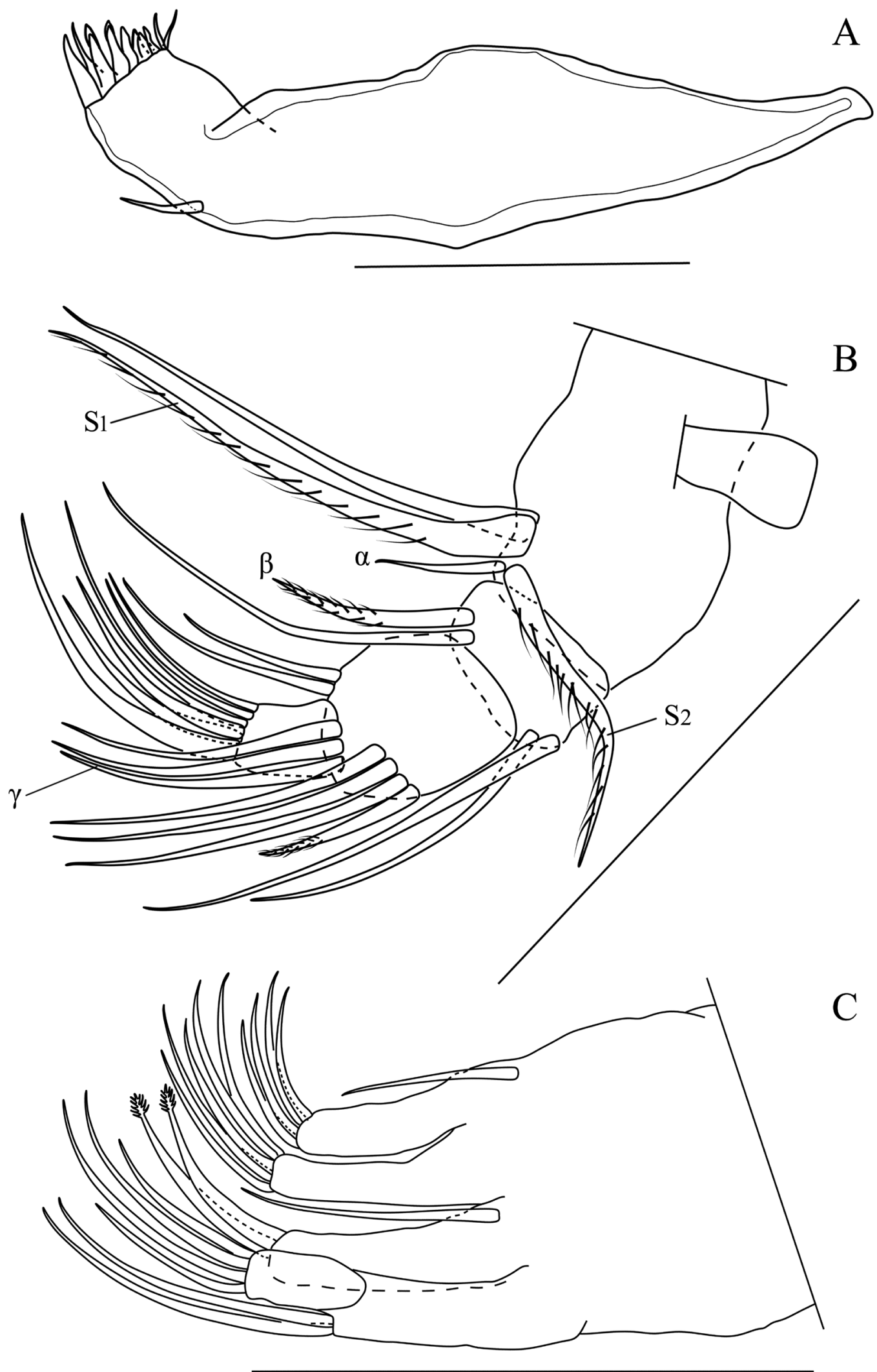

Fig. 20. Paranadopsis reducta gen. et sp. nov. from the Upper Paraná River floodplain, $\bigcirc$. A. Md (MZUSP 41869). B. Md-palp (MZUSP 41867). C. Mx1 (MZUSP 41867). Abbreviations: see text and Material and methods. Scale bars: $50 \mu \mathrm{m}$. 

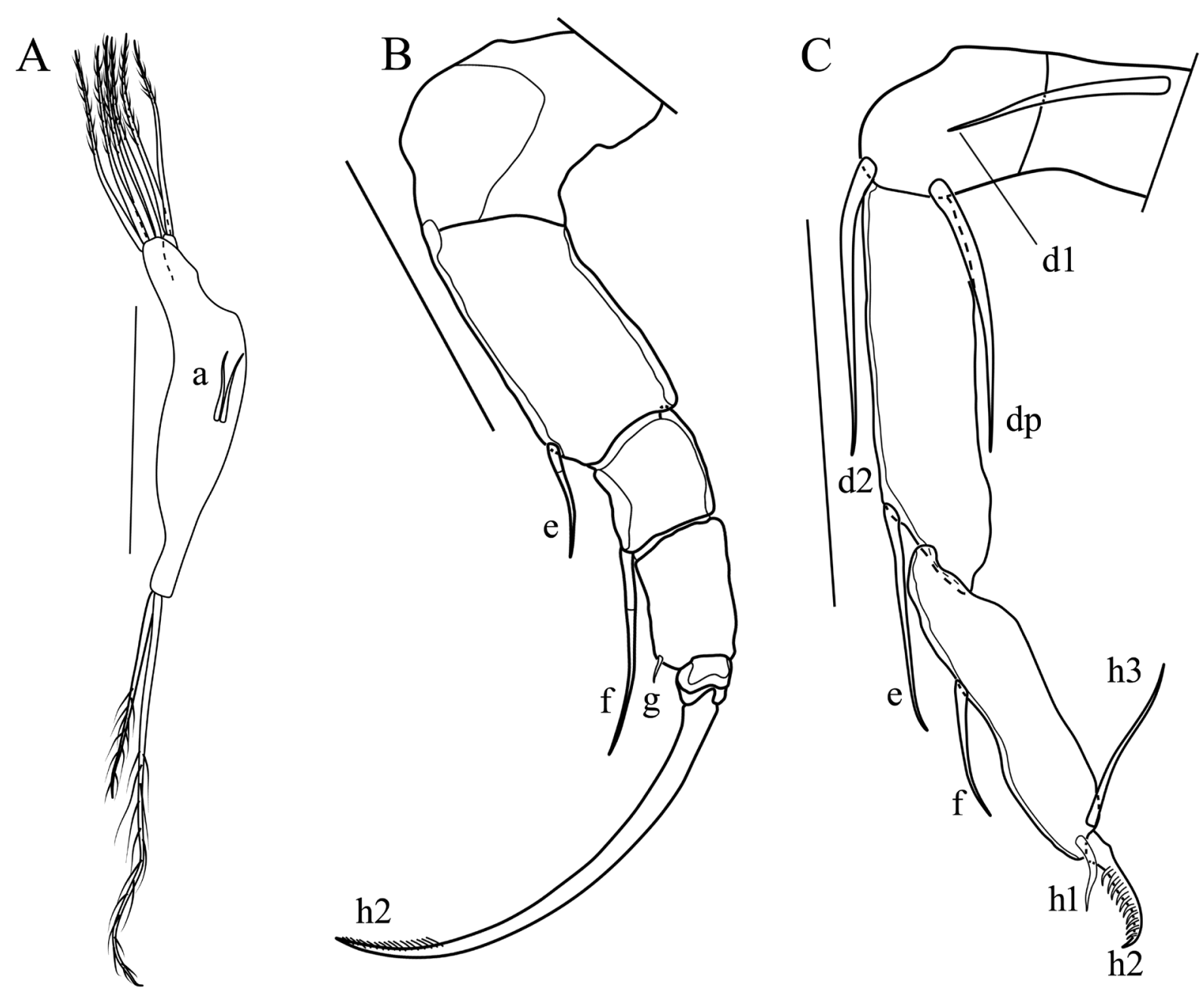

Fig. 21. Paranadopsis reducta gen. et sp. nov. from the Upper Paraná River floodplain, +. A. T1 (MZUSP 41868). B. T2 (MZUSP 41867). C. T3 (MZUSP 41869). Abbreviations: see text and Material and methods. Scale bars: $50 \mu \mathrm{m}$.

degrees of reduction, but never to the state of a flagellum. In the nominal subfamily Cypridopsinae, they included genera such as Cypridopsis Brady, 1867, Potamocypris Brady, 1870 and Zonocypris G.W. Müller, 1898, presently still considered as belonging to this subfamily, but also Oncocypris G.W. Müller, 1898 and Pseudocypretta Klie, 1932, both of which also have a flagellar CR. Oncocypris has meanwhile been transferred to the subfamily Oncocypridinae De Deckker, 1979 in the family Notodromadidae Kaufmann, 1900 by De Deckker (1979a, 1979b), while Pseudocypretta has meanwhile been transferred to the Cyprettinae, but might belong in the Cyprettadopsini Savatenalinton, 2020. Because at that stage, at least one other family in the Cypridoidea, the Notodromadidae, comprised a genus with flagellar CR, the main characteristic of the family Cypridopsidae was no longer unique to this family, and therefore De Deckker (1979a) argued (albeit implicitly) that this family should be merged (lowered to the rank of subfamily) in the family Cyprididae. Other researchers had already taken that position (McKenzie 1977 and others), however without further justification. One year later, Shornikov (1980) described the terrestrial genus Callistocypris Shornikov, 1980 with reduced CR and placed it in a separate subfamily, the Callistocypridinae in the family Cypridopsidae. Meanwhile, this subfamily is placed outside of the Cypridopsinae in the Cyprididae (see Meisch et al. 2019). The CR in Callistocypris is also not flagellar 
but reduced to a clear ramus and one claw-like seta (Shornikov 1980; Pinto et al. 2005), as in some species of Cypretta Vavra, 1895.

Within the Cypridoidea, the flagellar CR is rather an exception, as most species in this superfamily have a solid CR, consisting of a stout ramus and (generally) two claws and two setae. However, the other two superfamilies with representatives in non-marine habitats (Cytheroidea and Darwinuloidea) all have flagellar caudal rami, so either flagellar caudal rami in the Cypridoidea are the plesiomorphic character state, or they are an apomorphic condition resulting from a secondary reduction. The fact that several cypridoid lineages have such flagellar caudal rami does not help in deciding between these two evolutionary scenarios, as these lineages could either have retained the plesiomorphic state independently from each other or could have experienced parallel secondary reduction, or both processes could have been active. Either way, the presence of flagellar caudal rami is not a good character state on which to base a higher taxon, and even at the level of a subfamily, the monophyletic nature of the Cypridopsinae remains doubtful.

\section{Taxonomy of the Cypridopsinae}

An overview of the present generic taxonomy of the Cypridopsinae is given in Table 1. Five tribes (including Paranadopsini trib. nov.) and 21 genera (including Brasilodopsis gen. nov. and Paranadopsis gen. nov.) are presently included in this subfamily. The largest, and without doubt polyphyletic, tribe is still the Cypridopsini with 16 genera, divided in two groups: genera comprising species where the RV overlaps the LV and genera in which species have the LV overlapping the RV; the latter comprising the nominate genus Cypridopsis Brady, 1867. The Potamocypridini, rather obscurely defined in Ghetti \& McKenzie (1981), only comprise the genus Potamocypris Brady, 1870, the only cypridopsine genus with a spatulate second segment of the Mx1-palp (all other genera have a cylindrical segment there). Higuti \& Martens (2012) erected the tribe Zonocypridini, to comprise the genera Zonocypris G.W. Müller, 1898, mainly from Africa, and Cabelodopsis Higuti \& Martens, 2012 from Brazil. This tribe is characterised by a hyper developed claw G2 in the female A2. Savatenalinton (2018) added the genus Thaicypridopsis to this tribe. Recently, Savatenalinton (2020) added the tribe Cyprettadopsini for the enigmatic genus Cyprettadopsis Savatenalinton, 2020, which combines features of Cypridopsinae (flagellar CR), Cyprettinae (marginal septae) and even Candonidae (separate terminal segment of the T3). The relevance of the latter character will be discussed elsewhere, but Cyprettadopsis is probably a result of parallel evolution.

The above summary shows that delineating taxa in the Cypridopsinae, even at the level of tribes, generally relies on small differences in valve and/or soft part morphology, although there are exceptions, such as the remarkable species Thaicypridopsis longispinosa Savatanalinton, 2018 with unique spatulate and distally hirsute setae on all three endites of the Mx1. Siamopsis Savatenalinton, 2017, on the other hand is a case in point, where a species flock of five species in South East Asia is (correctly) united by a small 'plate' (expansion of the posterior calcified lamella) in the LV (Savatenalinton 2017). Also, the description of Brasilodopsis gen. nov. mainly relies on valve characters, nl. the presence /absence of inner lists in the valves.

\section{Position of Paranadopsis gen. nov.}

The situation of Paranadopsis gen. nov., however, is completely different as it shows reductions in size and chaetotaxy of segments in almost all limbs, but especially in the A1, whereas the CR is completely absent.

In the $\mathrm{A} 1$, segments 4 to 7 are reduced to tiny segments, with only a few setae. This is unique in the Cypridopsinae, and even in the Cyprididae. Such drastic reductions with loss of segments and setae, on the other hand, is not uncommon in interstitial Candonidae (for example Danielopol (1978); Martens 
(1992) on Namibcypris from Namibia; and Karanovic (2007) on interstitial candonids from the Pilbara regions in Western Australia), but are very rare in Cyprididae.

The A2 has only one natatory seta, which is again unique in this group. Natatory setae on the A2 are reduced in several other cypridopsine genera (e.g., Bryocypris Roen, 1956 (see redescription by Martens 1989), Klieopsis Martens, Meisch, Marmonier, 1991 (Martens et al. 1991) and Cavernocypris Hartmann, 1964 (redescribed by Marmonier et al.1989)), but never in such a way where only one seta remains and the others disappeared without at least a trace. Most likely this one remaining seta is actually the accompanying seta to the natatory setae, so that in effect only the latter are fully reduced.

In the Md-palp, the seta $\beta$ has only one accompanying seta, while there are only two apical setae on the first segment of the Mx1-palp. The T1 palp has only two (not three) apical setae, both setae d1 and $\mathrm{d} 2$ are missing from T2 and the caudal rami are fully lacking, as is also the case in Martenscypridopsis Karanovic \& Pesce, 2000 and Pseudocypridopsis Karanovic, 1999. It should also be noted that the cypridopsine CR can in generally only be found in females, as it is merged with the hemipenis in males (Martens \& Meisch 1985).

The genus Paranadopsis gen. nov. and the tribe Paranadopsini trib. nov. are thus very different from other Cypridopsinae and it is possible that this new genus actually deserves its own subfamily, much as Callistocypris is ranked outside of the Cypridopsinae. Future findings will show at which rank Paranadopsis gen. nov. should be classified, but at this stage we think it is important that the link with other cypridopsine genera is established by including it in the Cypridopsinae.

\section{Functional morphology of Paranadopsis reducta gen. et sp. nov.}

As mentioned above, a reduction of segments and setae is not uncommon in interstitial ostracods, especially in the Candonidae (Hartmann 1973; Danielopol 1978; Danielopol \& Hartmann 1986; Martens 1992). Nothing is known about the subterranean ostracod fauna from the Neotropical (Martens \& Behen 1994; Higuti \& Martens 2020), apart from some islands in the Caribbean (Broodbakker 1984) and we therefore do not know if this species, or other representatives of the genus and tribe, occur in interstitial or other subterranean habitats. However, Paranadopsis reducta gen. et sp. nov. was thus far only found in the pleuston of the root systems of floating plants such as Eichhornia crassipes, which are very common in South America. Dozens of other ostracod species can be found in the pleuston of this and other floating plants (Higuti et al. 2010) and none show similar morphological reductions. Therefore, life in pleuston does not seem to require such drastic morphological changes, hence we must assume that the observed reductions in size and chaetotaxy of segments on various limbs must either be adaptations to other habitat types or be the result of sexual selection (Tsukagoshi 1988; Martens 2000). Since parallel evolutions in other (mostly candonid) clades primarily occurred in subterranean habitats, explorations of these habitats in likely geological settings, such as karstic areas, are urgently required.

\section{Acknowledgments}

The samples of ostracods used in this study (from 2004 to 2018) result from the Long-Term Ecological Research (LTER - site 6, Long-Term Ecological Research) and National System of Biodiversity Research (SISBIOTA) programmes, supported by the Ministry of Science and Technology (MCT)/ National Council for Scientific and Technological Development (CNPq)/Fundação Araucária, and (from June 2003) result from Microbiota Biodiversity of Aquatic Ecosystems of the Nhecolândia Pantanal 2003-2004 project, supported by Foundation for the Support and Development of Education, Science and Technology of Mato Grosso do Sul (Fundação de Apoio e Desenvolvimento do Ensino, Ciência e Tecnologia do Mato Grosso do Sul - Fundect). 
We thank the Graduate Programme in Ecology of Inland Water Ecosystems (PEA), Centre of Research in Limnology, Ichthyology and Aquaculture (Nupélia) of the State University of Maringá (UEM), and USACUCAR, CORIPA, ICMBio for the logistic support. We thank Dr Kennedy Francis Roche and the Federal University of Mato Grosso do Sul for logistic support during sampling. NMA (scientific initiation's scholarship) and VGF (PhD's scholarship) would like to thank CNPq and CAPES for granting their scientific research, respectively. JH thanks CNPq for the research productivity scholarships. $\mathrm{Mr}$ Julien Cillis (Brussels, Belgium) assisted with the scanning electron microscope illustrations. The State University of Maringá and the Royal Belgian Institute of Natural Sciences (RBINS, Brussels) have a bilateral Memorandum of Understanding regarding collaborative Scientific Research.

\section{References}

Agostinho A.A., Gomes L.C., Thomaz S.M. \& Hahn N.S. 2004. The Upper Paraná River and its floodplain: main characteristics and perspectives for management and conservation. In: Thomaz S.M., Agostinho A.A. \& Hahn N.S. (eds) The Upper Paraná River and its Floodplain: Physical Aspects, Ecology and Conservation: 381-393. Backhuys Publishers, Leiden.

Aquino S., Latrubesse E.M. \& Souza-Filho E.E. 2008. Relações entre o regime hidrológico e os ecossistemas aquáticos da planície aluvial do Rio Araguaia. Acta Scientiarium, Biological Sciences 30: 361-369. https://doi.org/10.4025/actascibiolsci.v30i4.5866

Aquino S., Latrubesse E.M. \& Souza-Filho E.E. 2009. Caracterização hidrológica e geomorfológica dos afluentes da bacia do rio Araguaia. Revista Brasileira de Geomorfologia 10: 43-54.

https://doi.org/10.20502/rbg.v10i1.116

Broodbakker N. 1984. The distribution and zoogeography of freshwater Ostracoda (Crustacea) in the West Indies, with emphasis on species inhabiting wells. Bijdragen tot de Dierkunde 54: 25-50. https://doi.org/10.1163/26660644-05401003

Broodbakker N.W. \& Danielopol D.L. 1982. The chaetotaxy of Cypridacea (Crustacea, Ostracoda) limbs: proposals for a descriptive model. Bijdragen tot de Dierkunde 52: 103-120.

https://doi.org/10.1163/26660644-05202003

Campos R., Conceição E.O., Pinto M.B.O., Higuti J. \& Martens K. 2017. Evaluation of quantitative sampling methods in pleuston: an example from ostracod communities. Limnologica - Ecology and Management of Inland Waters 63: 36-41. https://doi.org/10.1016/j.limno.2017.01.002

Campos R., Lansac-Tôha F.M., Conceição E.O., Martens K. \& Higuti J. 2018. Factors affecting the metacommunity structure of periphytic ostracods (Crustacea, Ostracoda): a deconstruction approach based on biological traits. Aquatic Sciences 80: 1-12. https://doi.org/10.1007/s00027-018-0567-2

Campos R., Conceição E.O., Martens K. \& Higuti J. 2019. Extreme drought periods can change spatial effects on periphytic ostracod metacommunities in river-floodplain ecosystems. Hydrobiologia 828: 369-381. https://doi.org/10.1007/s10750-018-3825-3

Conceição E.O., Higuti J. \& Martens K. 2017. Variability in ostracod communities (Crustacea, Ostracoda) in connected and isolated tropical floodplain lakes. Annales de Limnologie - International Journal of Limnology 53: 325-332. https://doi.org/10.1051/limn/2017016

Conceição E.O., Higuti J., Campos R. \& Martens K. 2018. Effects of flood pulses on persistence and variability y of pleuston communities in a tropical floodplain lake. Hydrobiologia 807: 175-188. https://doi.org/10.1007/s10750-017-3392-z 
Danielopol D.L. 1978. Über Herkunft und Morphologie der Süsswasser-hypogäische Candoninae (Crustacea, Ostracoda). Sitzungsberichte der Österreichischen Akademie der Wissenschaften, mathematisch-naturwissenschaftliche Klasse 187 (1-5): 1-162.

Danielopol D.L. \& Hartmann G. 1986. Ostracoda. In: Botosaneanu L. (ed.) Stygofauna Mundi: 259294. E.S. Brill, Leiden.

De Deckker P. 1979a. Comparative morphology and review of Australian Notodromadinae Kaufmann, 1900. Senckenbergiana Biologiae: 59 (5/6): 417-463.

De Deckker P. 1979b. Evaluation of features distinctive in the taxonomy of the Cypridacea above the generic level. In: Krstić N. (ed.) Proceedings of the VII th International Symposium on Ostracodes. Taxonomy, Biostratigraphy and Distribution of Ostracodes: 9-17. Serbian Geological Society, Beograd.

Ghetti P.F. \& McKenzie K.G. 1981. Ostracodi (Crustacea, Ostracoda). Guide per il riconoscimento delle specie animali delle acque interne Italiane. C.N.R. AQ/1/108, 11: 83.

Hartmann G. 1963. Zur Phylogenie und Systematik der Ostracoden. Zeitschrift fur zoologische und systematische Evolutionsforschung 1: 1-154. https://doi.org/10.1111/j.1439-0469.1963.tb01626.x

Hartmann G. 1973. Zum gegenwärtigen Stand der Erforschung der Ostracoden interstitieller Systeme. Annales de Spéléologie 28: 417-426.

Hartmann G. \& Puri H.S. 1974. Summary of Neontological and Paleontological Classification of Ostracoda. Mitteilungen aus dem Hamburgischen zoologischen Museum und Institut 70: 7 -73.

Higuti J. \& Martens K. 2012. On a new cypridopsine genus of ostracods (Crustacea, Ostracoda, Cyprididae) from the Upper Paraná River Floodplain (Brazil). Zootaxa 3391: 23-38.

https://doi.org/10.11646/zootaxa.3391.1.2

Higuti J. \& Martens K. 2016. Invasive South American floating plants are a successful substrate for native Central African pleuston. Biological Invasions 18:1191-1201.

https://doi.org/10.1007/s10530-016-1061-1

Higuti J. \& Martens K. 2020. Chapter 20. Class Ostracoda. In: Damborena M.C., Rogers D.C. \& Thorp J.H. (eds) Thorp \& Covich's Freshwater Invertebrates, $4^{\text {th }}$ Edition, Volume V: Keys to the Neotropical Fauna: 631-661. Academic Press, London. https://doi.org/10.1016/B978-0-12-804225-0.00020-4

Higuti J., Velho L.F.M., Lansac-Tôha F.A. \& Martens K. 2007. Pleuston communities are buffered from regional flood pulses: the example of ostracods in the Paraná River floodplain, Brazil. Freshwater Biology 52: 1930-1943. https://doi.org/10.1111/j.1365-2427.2007.01821.x

Higuti J., Velho L.F.M., Lansac-Tôha F.A. \& Martens K. 2009. Biodiversity of non-marine ostracods (Crustacea, Ostracoda) in the alluvial valley of the upper Paraná River, Brazil. Brazilian Journal of Biology 69: 661-668. https://doi.org/10.1590/S1519-69842009000300020

Higuti J., Declerck S.A.J., Lansac-Tôha F.A., Machado Velho L.F. \& Martens K. 2010. Variation in ostracod (Crustacea, Ostracoda) communities in the alluvial valley of the upper Paraná River (Brazil) in relation to substrate. Hydrobiologia 644: 261-278. https://doi.org/10.1007/s10750-010-0122-1

Higuti J., Roche K.F. \& Martens K. 2017a. Checklist de ostrácodes (Crustacea, Ostracoda) dulcícolas do Pantanal Sul Mato-grossense, Brasil. Iheringia, Série Zoologia (Online) 107 (suppl.): e2017114. https://doi.org/10.1590/1678-4766e2017114

Higuti J., Conceição E.O., Campos R., Ferreira V.G., Rosa J., Pinto M.B.O. \& Martens K. 2017b. Periphytic community structure of Ostracoda (Crustacea) in the river-floodplain system of the Upper Paraná River. Acta Limnologica Brasiliensia 29: 1-17. https://doi.org/10.1590/s2179-975x12217 
Higuti J., Rosa J., Ferreira V.G., Almeida N.M., de Campos R., Conceição E.O. \& Martens K. 2020. Inter-annual variation of ostracod (Crustacea) communities in the Upper Paraná River floodplain, Brazil. Oecologia Australis 24 (1): 474-488. https://doi.org/10.4257/oeco.2020.2402.17

Horne D.J., Cohen A. \& Martens K. 2002. Taxonomy, morphology and biology of Quaternary and living Ostracoda. In: Holmes A.J. \& Chivas A.R. (eds) The Ostracoda: Applications in Quaternary Research: 5-36. AGU Geophysical Monograph Series 131. https://doi.org/10.1029/131GM02

Irion G., Junk W.J., \& de Mello J.A.S.N. 1997. The large Central Amazonian River floodplains near Manaus: geological, climatological, hydrological and geomorphological aspects. In: Junk W.J. (ed.) The Central Amazon Floodplain. Ecological Studies (Analysis and Synthesis): 23-46. Springer, Berlin and Heidelberg. https://doi.org/10.1007/978-3-662-03416-3_2

Karanovic I. 2007. Candoninae (Ostracoda) from the Pilbara Region in Western Australia. Brill Crustaceana Monographs. https://doi.org/10.1163/ej.9789004156937.i-434

Kaufmann A. 1900. Cypriden und Darwinuliden der Schweiz. Revue suisse de Zoologie 8: 209-423. https://doi.org/10.5962/bhl.part.10584

Latrubesse E.M. \& Stevaux J.C. 2002. Geomorphology and environment aspects of the Araguaia fluvial basin, Brazil. Zeitschrift fur Geomorphologie 129: 109-127.

Latrubesse E.M. \& Stevaux J.C. 2006. Características físico-bióticas e problemas ambientais associados à planície aluvial do Rio Araguaia, Brasil Central. Revista Goiana de Geociências 5: 65-73.

Marmonier P., Meisch C. \& Danielopol D.L. 1989. A review of the genus Cavernocypris Hartmann (Ostracoda, Cypridopsinae): Systematics, Ecology and Biogeography. Bulletin de la Société des Naturalistes luxembourgeoises 89: 221-278.

Martens K. 1987. Homology and functional morphology of the sexual dimorphism in the antenna of Sclerocypris Sars, 1924 (Crustacea, Ostracoda, Megalocypridinae). Bijdragen tot de Dierkunde 57: 183-190. https://doi.org/10.1163/26660644-05702003

Martens K. 1989. On Bryocypris grandipes Røen. Stereo-Atlas of Ostracod Shells 16 (29): 140-147.

Martens K. 1992. On Namibcypris costata n.gen. n.sp. (Crustacea, Ostracoda, Candoninae) from a spring in northern Namibia, with the description of a new tribe and a discussion on the classification of the Podocopina. Stygologia 7 (1): 27-42.

Martens K. 2000. Factors affecting the divergence of mate recognition systems in the Limnocytherinae (Crustacea, Ostracoda). Hydrobiologia. 419: 83-101. https://doi.org/10.1023/A:1003954513004

Martens K. \& Behen F. 1994. A Checklist of the non-marine Ostracods (Crustacea, Ostracoda) from South-American Inland Waters and adjacent Islands. Travaux scientifiques du Musée d'Histoire naturelle de Luxembourg 22. Musée d'Histoire naturelle, Luxembourg.

Martens K. \& Meisch C. 1985. Description of the male of Potamocypris villosa (Jurine, 1820) (Crustacea, Ostracoda). Hydrobiologia 127: 9-15. https://doi.org/10.1007/BF00004658

Martens K., Meisch C. \& Marmonier P. 1991. On Klieopsis n.gen., with a redescription of Cypridopsis horai Klie, 1927 (Crustacea, Ostracoda). Bulletin van het Koninklijk Belgisch Instituut voor Natuurwetenschappen, Biologie 61: 55-64.

Matsuda J.T., Lansac-Tôha F.A., Martens K., Velho L.F.M., Mormul R.P. \& Higuti J. 2015a. Association of body size and behavior of freshwater ostracods (Crustacea, Ostracoda) with aquatic macrophytes. Aquatic Ecology 49 (3): 321-331. https://doi.org/10.1007/s10452-015-9527-2 
Matsuda J.T., Martens K. \& Higuti J. 2015b. Diversity of ostracod communities (Crustacea, Ostracoda) across hierarchical spatial levels in a tropical floodplain. Hydrobiologia 762 (1): 113-126.

https://doi.org/10.1007/s10750-015-2342-x

McKenzie K.G. 1977. Illustrated generic key to South African continental Ostracoda. Annals of the South African Museum 74: 45-103.

Meisch C. 2000. Freshwater Ostracoda of western and central Europe. Spektrum Akademischer Verlag $\mathrm{GmbH}$, Heidelberg.

Meisch C., Smith R.J. \& Martens K. 2019. A subjective global checklist of the extant non-marine Ostracoda (Crustacea). European Journal of Taxonomy 492: 1-135. https://doi.org/10.5852/ejt.2019.492

Pereira L.C., Lansac-Tôha F.A., Martens K. \& Higuti J. 2017. Biodiversity of ostracod communities (Crustacea, Ostracoda) in a tropical floodplain. Inland Waters 7: 323-332.

http://doi.org/10.1080/20442041.2017.1329913

Pinto R.L., Rocha C.E.F. \& Martens K. 2005. On new terrestrial ostracods (Crustacea, Ostracoda) from Brazil, primarily from Sao Paulo State. Zoological Journal of the Linnean Society 145: 145-173. https://doi.org/10.1111/j.1096-3642.2005.00185.x

Por F.D. 1995. The Pantanal of Mato Grosso (Brazil). World's Largest Wetlands. Kluwer Academic, Dordrecht. https://doi.org/10.1007/978-94-011-0031-1

Savatenalinton S. 2017. Siamopsis gen. nov. and five new species of the subfamily Cypridopsinae Kaufmann, 1900 (Crustacea: Ostracoda) from Thailand. European Journal of Taxonomy 384: 1-39. https://doi.org/10.5852/ejt.2017.384

Savatenalinton S. 2018. New genus of subfamily Cypridopsinae Kaufmann, 1933 (Crustacea, Ostracoda) from Thailand. European Journal of Taxonomy 384: 1-17. https://doi.org/10.5852/ejt.2018.487

Savatenalinton S. 2020. A new cypridopsine genus (Crustacea, Ostracoda) from Thailand. European Journal of Taxonomy 631: 1-16. https://doi.org/10.5852/ejt.2020.631

Shornikov E. 1980. Ostracodes in terrestrial biotopes. Zoologicheskii Zhurnal 59: 1309-1319.

Tsukagoshi A. 1988. Reproductive character displacement in the ostracod genus Cythere. Journal of Crustacean Biology 8: 563-575. https://doi.org/10.1163/193724088X00413

Manuscript received: 18 December 2020

Manuscript accepted: 20 May 2021

Published on: 4 August 2021

Topic editor: Rudy C.A.M. Jocqué

Desk editor: Kristiaan Hoedemakers

Printed versions of all papers are also deposited in the libraries of the institutes that are members of the EJT consortium: Muséum national d'histoire naturelle, Paris, France; Meise Botanic Garden, Belgium; Royal Museum for Central Africa, Tervuren, Belgium; Royal Belgian Institute of Natural Sciences, Brussels, Belgium; Natural History Museum of Denmark, Copenhagen, Denmark; Naturalis Biodiversity Center, Leiden, the Netherlands; Museo Nacional de Ciencias Naturales-CSIC, Madrid, Spain; Real Jardín Botánico de Madrid CSIC, Spain; Zoological Research Museum Alexander Koenig, Bonn, Germany; National Museum, Prague, Czech Republic. 